DOI https://doi.org/10.36059/978-966-397-241-1-27

\begin{abstract}
Д'яченко I. М.
кандидат філософських наук, доцент, доцент кафедри природничих та соціально-гуманітарних дисциплін Житомирський медичний інститут Житомирської обласної ради м. Житомир
\end{abstract}

Гордійчук С. B.

доктор педагогічних наук, кандидат біологічних наук, доцент, проректор з навчальної роботи Житомирський медичний інститут Житомирської обласної ради м. Житомир

Круковська I. М.

кандидат педагогічних наук, доцент, завідувач кафедри природничих та соціально-гуманітарних дисциплін Житомирський медичний інститут Житомирської обласної ради м. Житомир

Журавська Л. Л.

методист відділу технічних засобів навчання Житомирський медичний інститут Житомирської обласної ради м. Житомир

\title{
СУЧАСНІ ЄВРОПЕЙСЬКІ ТЕНДЕНЦІЇ ОСВІТИ ТА ГЕНЕРАЛЬНИЙ ЦІННІСНИЙ ВЕКТОР ПРОФЕСІЙНОЇ ПІДГОТОВКИ МЕДИЧНИХ ПРАЦІВНИКІВ
}

Сучасні зміни в системі освіти накладають високий рівень вимог до здобувачів медичної освіти. Особливо гостро стоїть проблема відповідності цінностей медичного працівника цінностям соціуму, який постійно змінюється. Дослідження ціннісної сфери респондентів виявило пріоритет цінності «любові до житті» в ієрархічній структурі системи. Визначена генеральна тенденція серед респондентів, в світоглядній структурі яких домінує цінність 
«любові до життя»: 1) вони відзначаються кращим станом здоров'я й показують менший рівень кількості хронічних захворювань; 2) приділяють менше значення руховим вмінням та навичкам та більше - перцептивним навичкам і емпатії у професійній діяльності медичної сестри; 3) високо оцінюють соціальне значення професій медичної сестри, відповідно особисті та професійні якості: милосердя, наполегливість, доброта, охайність, захопленість своєю роботою, бездоганне виконання професійних обов'язків, уважність та інтуйція, повага до пацієнта і його родини; 4) усвідомлюють необхідність постійного удосконалення та освіти.

Отже, генеральна цінність сучасних майбутніх $і$ працюючих медичних працівників відповідають стратегічним векторам руху системи освіти, що дозволяє розглядати їх як рушійну силу змін української медищини у форматі Education 5.0.

\section{Вступ}

Освіта - це дзеркало змін, що відбуваються в людині, в суспільстві, в світі. Сьогодення освіти визначають у тому числі наступні тенденції-проблеми: 1) розмитість причини відвідування молоддю закладів освіти, оскільки сьогодні практично будь-які знання можна легко отримати з будь-якого місця у будь-який час доби та за мінімальну плату; 2) більшість учнів/студентів не знають жодної мети відвідування навчального закладу, крім обов'язку; 3) викладання як професія та освіта в цілому як система повинні просто адаптуватися до нових обставин та змін у ролі: від виконавця навчальних програм до тренера з навчання. Нова функція полягає в тому, щоб підживлювати природну пристрасть і геніальність учня, а не бути захисниками знань, змушуючи учнів йти заздалегідь прокладеним шляхом, створеним для мас; 4) перехід від методики критицизму до методики залучення студентів ставити під сумнів знання та методи, що викладаються вчителями, і знаходити нові інноваційні ідеї як індивідуально, так і колективно; 5) зміна застарілих та несучасних обмежень систем, у яких працюють вчителі/викладачі; 6) перетворення корумпованої системи освіти на нову систему, що потребує революції світогляду всіх учасників освітнього процесу; 7) глобальний взаємозв'язок, розумні машини, нові медіа, що розвиваються; 8) мультифункціональні навички роботи та безперервна освіта в майбутньому. Концепція «100річного життя», яка стає нормою і більшу частину якої займає навчання та робота, означає, що навчання матиме набагато більше 
значення для наступних поколінь. У більшості людей буде безліч різних професій, що вимагають фундаментального перенавчання, а швидкість інновацій постійно вимагатиме нових навичок та знань для підтримки темпу; 9) постійна переоцінка цінності та значущості освіти та бізнесу у новому соціальному, діловому та економічному ландшафті; 10) освіта 5.0 - до вирішення проблем та створення цінностей.

Очевидно, що усі проблеми в системі сучасної освіти зводяться до однієї головної: консервативність освіти проти мобільності сучасного суспільства, рішення якої, в свою чергу, передбачає перехід від критичного мислення до «складного мислення» [1, с. 20-22], до міжкультурної комунікації, включення людини в загальну картину світу, переосмислення співвідношення індивідуальних цінностей та цінностей соціуму. Новий спосіб мислення вимагає діалогу між усіма учасниками освітнього процесу заради формування ціннісної основи сучасного світогляду особистості в мобільному суспільстві.

Справедливо буде сказати, що різкі зміни у світі праці та зайнятості означають, що в основу нового світу освіти прагнуть закласти цінності стійкості та адаптивності.

Ми прагнули дослідити ціннісний світ майбутніх медичних працівників і тих, хто має досвід роботи в медицині, з метою виявити генеральний ціннісний вектор їхнього світогляду та співвіднести його з тими цінностями, що визначаються як магістральні нового світу освіти, прогресу в ньому.

\section{1. Прогрес в освіті: від Education 1.0. до Education 5.0.}

Використання технологій в освіті, починаючи 3 XIX століття, переслідує одну мету: звільнити людину з-під нав'язливої опіки, максимальної функціональної залежності від суспільства, підвищити активність людини. Між 1840-1850 рр. в освіті використовували одностороннє заочне навчання з використанням різних засобів поштового зв'язку, радіо і телебачення. У період з 1960-х по 1990-ті роки стали використовувати навчальні машини i запрограмоване навчання, за ним - комп'ютеризовані навчальні програми. Мережеві технології були визнані новаторськими інноваціями в галузі освіти в середині 1990-х років.

У період Education 1.0. веб-інструменти використовувалися тільки для надання односторонньої інформації. Протистояння учитель/ викладач-учні/студенти зберігалося, роль учня/студента 
залишалася пасивною, підходи до навчання були традиційні: учитель/викладач - інформаційний передавач - учні/студентиспоживачі знань.

Освіта була процесом вкладення, у якому учні/студенти $\epsilon$ депозитаріями, а вчитель/викладач - вкладником. Замість спілкування, учитель/викладач формує і вкладає повідомлення в учнів/студентів, які терпляче його приймають, запам'ятовують i відтворюють. Таку модель освіти П. Фрейре влучно назвав «банківською» [2, с. 54]. За «банківською» моделлю освіти обсяг операцій, дозволених тим, хто навчається, охоплює лише приймання, розкладання по поличках та зберігання вкладеного. Функції тих, хто навчає (вчитель/виклдач), в «банківській» освітній моделі: 1) вчитель вчить, а учні вчаться; 2) вчитель знає все, а учні нічого; 3) вчитель думає, а за учнів думають; 4) вчитель говорить, а учні слухають покірно; 5) вчитель дисциплінує, а учні підкоряються; 6) вчитель обирає й нав'язує свій вибір, а учні погоджуються; 7) вчитель діє, а учні мають ілюзію, що діють через дії вчителя; 8) вчитель визначає зміст програми, а учні, яких ніхто не питав, пристосовуються до неї; 9) вчитель змішує владу знання з власною професійною владою, яку він (вона) встановлює на противагу свободі учнів; 10) вчитель - Суб'єкт навчального процесу, учні - його прості Об'єкти [2, с. 55].

Очевидно, що «банківська» модель освіти вважає людей керованими істотами і більшій мірі, ніж істотами, які мають власну критичну свідомість та потенціал, творчу спроможність. Чим довірливіше учні/студенти приймають підготовлену для них пасивну роль, тим більше стають схильні просто адаптуватися до такого світу, який він $\epsilon$, і звикають до навіяної вчителями фрагментарної реальності. За такого підходу людина не $\epsilon$ свідомою істотою, вона скоріше має не свідомість, а порожній мозок, пасивно відкритий для сприйняття вкладеної в нього реальності з зовнішнього світу. 3 «банківського» розуміння свідомості логічно випливає, що роль педагога полягає в регулюванні способу проникнення світу в учня, а завдання вчителя - організувати процес наповнення учнів, вкладаючи в них інформацію, тобто «істинне знання».

Таким чином, оскільки людина «отримує» світ як пасивна сутність, освіта має зробити людей ще пасивнішими та адаптувати до цього світу. Освічена людина - це адаптована особа, тому що вона «краще» пристосована до світу, який не змінюється!? Відстань та протиріччя між учителем/викладачем і учнем/студентом зростає. 
В період Education 2.0., який активізував зміни ролі вчителя/ викладача і характер відносин з учнями/студентами, з 2004 р. почали використовувати технологій Web 2.0. 3'явилися цифрові навчальні платформи, які істотно вплинули на учасників і сам процес освіти.

У 2010 р. на перший план вийшли віртуальні середовища навчання, характерні для Education 3.0., які сприяли масовізації освіти, посиленню акценту на практиці навчання.

3 появою Industry 4.0. почався новий період Education 4.0. 3 домінуванням цифровий трансформації не тільки в освіті, а й у багатьох сферах життя і діяльності людини [3].

До 2021 р змінилося більше третини навичок (35\%), які вважаються важливими в сьогоднішній робочій силі. До 2021 р. Четверта промислова революція принесла нам сучасну робототехніку і автономний транспорт, штучний інтелект і машинне навчання, передові матеріали, біотехнологію, геноміку та дистанційну освіту [4]. Безумовно, майбутня робоча сила повинна буде погодити свій набір навичок, щоб йти в ногу з часом. У 2015 р. в доповіді Форуму «Майбутнє робочих місць» [5] розглядалася стратегія зайнятості, навичок і робочої сили на майбутнє, що означало поточні зрушення, зокрема, для зайнятості, навичок i набору персоналу в різних галузях і регіонах.

Порівняльний аналіз найбільш значущих навичок в 2015 р. з 2020 p. дозволяє з робити висновки про тенденції зміни актуальних навичок сучасних людей, які взяті на озброєння усіма системами освіти світу:

Таблиця 1

\begin{tabular}{|l|l|l|}
\hline \multicolumn{1}{|c|}{$\mathbf{2 0 2 0}$ p. } & \multicolumn{1}{|c|}{$\begin{array}{c}\text { Основні навички } \\
\text { сучасної людини }\end{array}$} & \multicolumn{1}{c|}{$\mathbf{2 0 1 5} \mathbf{p .}$} \\
\hline \multicolumn{1}{|c|}{1} & \multicolumn{1}{c|}{2} & \multicolumn{1}{c|}{3} \\
\hline $\begin{array}{l}\text { 1. complex problem } \\
\text { solving }\end{array}$ & Комплексне рішення проблем & $\begin{array}{l}\text { 1. complex problem } \\
\text { solving }\end{array}$ \\
\hline 2. critical thinking & Критичне мислення & $\begin{array}{l}\text { 2. coordinating with } \\
\text { others }\end{array}$ \\
\hline 3. creativity & Креативність/нестандартність & $\begin{array}{l}\text { 3. people } \\
\text { management }\end{array}$ \\
\hline $\begin{array}{l}\text { 4. people } \\
\text { management }\end{array}$ & Управління людьми & 4.critical thinking \\
\hline $\begin{array}{l}\text { 5. coordinating with } \\
\text { others }\end{array}$ & Координація з іншими & 5. negotiation \\
\hline
\end{tabular}


Педагогіка XXI століття: сучасний стан та тенденції розвитку

\begin{tabular}{|c|c|c|}
\hline \multicolumn{3}{|r|}{ Закінчення таблиці 1} \\
\hline 1 & 2 & 3 \\
\hline $\begin{array}{l}\text { 6. emotional } \\
\text { intelligence }\end{array}$ & $\begin{array}{l}\text { Емоційний інтелект } \\
\text { Контроль якості }\end{array}$ & $\begin{array}{l}\text { 6. quality control } \\
\text { emotional } \\
\text { intelligence }\end{array}$ \\
\hline $\begin{array}{l}\text { 7. judgment and } \\
\text { decision making }\end{array}$ & $\begin{array}{l}\text { Судження та прийняття } \\
\text { рішень }\end{array}$ & 7. service orientation \\
\hline 8. service orientation & \begin{tabular}{|l} 
Орієнтація \\
на обслуговування
\end{tabular} & $\begin{array}{l}\text { 8. judgment and } \\
\text { decision making }\end{array}$ \\
\hline 9. negotiation & $\begin{array}{l}\text { Переговори } \\
\text { Активне слухання }\end{array}$ & 9. active listening \\
\hline $\begin{array}{l}\text { 10. cognitive } \\
\text { flexibility }\end{array}$ & Пізнавальна гнучкість & 10. creativity \\
\hline
\end{tabular}

Отже, 1) в порівнянні з 2015 р зникли з ієрархії актуальних навичок «контроль якості» і «активне слухання»; 2) у 2020 г. з'являється в реєстрі затребуваних навичок людини «пізнавальна гнучкість»; 3) змінилася ієрархія навичок: креативність/нестандартність 310 місця піднялася на 3-е місце; «Переговори» опустилися з 5-го місця на 9-е; «Критичне мислення» 3 4-го місця піднялося на 2-е; «Координація з іншими» 32 2-го місця опустилася на 5-е; а «Орієнтація на обслуговування» змінилася місцем з навичкою «Судження і прийняття рішень», яка посилила свої позиції, перемістившись з 8-го на 7-е місце; 4) на найближче майбутнє очевидно посилення позицій, значущості навичок «Креативність/ нестандартність», «Критичне мислення», «Судження і прийняття рішень», а також поява в структурі навичок «Пізнавальної гнучкості» на тлі зниження рейтингу значущості «Координація 3 іншими», «Переговори», «Орієнтація на обслуговування», «Управління людьми», зникнення навичок «Активне слухання», «Контроль якості». Все це свідчить про посилення тенденції індивідуалізації, десоціализації, відповідно нейтралізації розвитку конвенціональних навичок людини, 3 одного боку. 3 іншого, очевидно, посилення процесів самопізнання та самореалізації на фоні загострення потреб у самовизначеності та самоствердженні. Крім того, вирішення постіндустріальних проблем викристалізовує нові цінності.

Продуктивний підхід до Education 4.0. передбачає орієнтацію на персоналізоване навчання, при якому використовуються найбільш підходящі методи навчання і програми, що максимально повинні відповідати індивідуальним потребам і потенціалові учнів. 
Education 4.0. [6] представлено різними парадигмами: 1) sensemaking (почуття-створення); 2) growth mind-set (зростання мислення); 3) creative-thinking (творче мислення); 4) STEAM (Science, Technology, Engineering, Art and Math - наука, технології, інженерія, мистецтво та математика); 5) learning (навчання); 6) classroom in the clouds (клас у хмарах); 7) coding (кодування); 8) fipeed learning (зворотне навчання); 9) maker learning (навчання творців) [7].

Не дивлячись на всі привабливі ідеї, в умовах Education 4.0 визначається та загострюється ряд проблем, серед яких, по-перше, проблема редукції освітнього і суб'єктивно-антропологічного, яка губить можливість схопити сутність освіти, виявити імітацію рівності, доступності та якості освіти, знецінює не тільки індивідуально-родовий потенціал людини, а й життя в цілому.

Будь-яка ідея вдосконалення суспільства і відповідно системи освіти грунтується на емансипації, яка традиційно розуміється як вихід зі стану незрілості.

Згідно 3 педагогічної логікою, емансипація передбачає необхідність існування для незрілого індивіда (класу, народу) освіченого наставника/вчителя, провідника, який здатний вказати шлях до звільнення і зрілості індивіда. Наставник-провідник $є$ необхідною умовою прогресу для тих, хто застряг в ситуації незнання, нав'язаних ідентифікацій.

Освічений вчитель завжди зберігає між собою і тими, хто вчиться, дистанцію-знання, яку він утримує за собою і яку учні ніколи не подолають, будуть наздоганяти, як Ахіллес черепаху, з вічним відставанням.

Роль і функції «освіченого вчителя» може виконувати в тому числі і віртуальне середовище, наприклад, в контексті Education 4.0., або цифрова освіта, мережеві технології, робототехніка.

Однак, при цьому дистанція між «освіченим учителем» і учнем зберігається, як і ілюзія самостійної активності тих, хто навчається. Учень або студент, будь-хто, хто навчається все одно має статус того, кого ведуть, за кого вирішують тощо, в якій би завуальованій формі це не подавалося.

Необхідна демістифікація ідей «цифрове суспільство», «віртуальна реальність», «суспільство 5.0.», «Education 5.0.», а також зв'язку технологічного прогресу зі свободою, рівністю, інтеграцією. Ніщо з цього не $\epsilon$ кінцевою метою, яку людині треба досягти, не $\epsilon$ точкою відліку, засобом, що відкриває шлях для контролю, управління, регулювання всім тим, що існує об’єктивно. 
Треба знову розвернутися до людини, без розуміння якої, сумнівна успішна реалізація будь-яких проектів, в тому числі і цифрових [8].

По-друге, - це проблема протистояння цінностей, тих, які «створюються», тим, які пов'язані із природою людини, живого в цілому.

\section{2. Генеральна цінність майбутніх \\ і працюючих медичних працівників}

Формування інноваційного світу вимагає від студентів активності в процесах здобування, структурування, розробки, оцінки нової інформації [9]. Активними вони можуть бути тільки у ситуації відповідності діяльності цінностям самої особистості та професії, яку обрали, якої навчаються, тому що цінності $\epsilon$ формою прояву цілі [8].

Ми у 2019-2021 рр. провели дослідження, зосередивши увагу на генеральній цінності студентів медичного закладу та медичних працівників, що мають досвід роботи не менше 5 років.

Завдання нашого пошуку зводилося до того, щоб виявити генеральну цінність та визначити наслідки співпадіння або розходження генеральної цінності 3 мотиваціями діяльності (освітянської, професійної) та установками Education 4.0, суспільству 5.0. здоров'ю молоді, яка навчається та працює в Україні (на прикладі м. Житомира).

Виборка респондентів складала 220 людей(усі жінки), з яких 110 - студенти-Житомирського медичного інститут та 110 медсестри, які здійснюють трудову діяльність в обласній клінічній лікарні 5 і більше років (рис. 1).

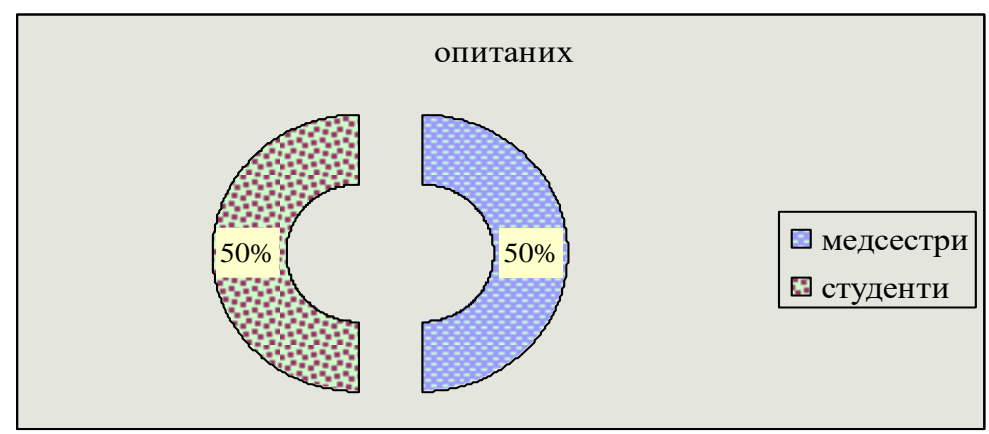

Рис. 1. Структура опитуваних респондентів 
Усі респонденти були умовно розподілені за віковими групами: $\leq 20$ років ; 21-25 років; 26-35 років; 36-45 і більше років. 3бір соціальної інформації проводився за допомогою анкетування (анкета складалася із 21 запитання).

Так, на перше ж питання анкети: «життя - це...», відповіді респондентів були неоднозначними. Працюючі медсестри в переважаючій більшості (80\%), а серед медсестер-студентів лише 26\%, обрали за відповідь вираз - «Божий дар». Можливо тому, що життя не може бути в повному розпорядженні лише людей і воно не може бути об'єктом маніпуляції людьми, як їхня власність. При цьому, 3\% опитаних працюючих медсестер і 11\% медсестерстудентів співвіднесли поняття «життя» із Всесвітом, оскільки підтримують думку, що Життя в космосі існувало ще до появи Сонячної системи, Всесвіт є живим, люди - гості на планеті Земля. 4\% опитаних медсестер і 9\% студентів вважають, що життя - це «знання», бо людина з кожною миттю здобуває нові знання для свого існування. 5\% опитаних медсестер і 8\% студентів вважають, що життя - це «буття» у різних його формах. Припустимо, що малось на увазі, специфічний спосіб унікального, неповторного існування людини, особлива реальність, збагнення якої дозволяє людині краще зрозуміти саму себе. Принциповим $є$ те, що майже половина медсестер-студентів (50 осіб або 46\%) і лише 5\% працюючих медсестер визначили «життя» як «форму існування білкових тіл». Можна припустити, що студенти обрали таку відповідь 3 абстрактної або навчальної точки зору, оскільки медична наука скоріше розглядає життя як явище, що є сукупністю фундаментальних загально біологічних ознак (метаболізму, гомеостазу, розвитку, відповіді на подразнення, розмноження, еволюції тощо), які характеризують живих істот, відрізняючи їх від неживих об'єктів. Життя визначається як форма існування матерії, найхарактернішими рисами якої $\epsilon$ обмін речовин, самооновлення та самовідтворення. А працюючі медсестри вже дещо стомилися від життєвих негараздів, тому для них життя - важке буття. Лише один респондент серед працюючих медсестер дав власний варіант відповіді: «Життя - це нескінчене завоювання невідомого, жити значить боротися, боротися за своє місце під сонцем». 
Таблиця 2

Питання №». 1. Життя - це...? (Цінність любові до життя)

\begin{tabular}{|c|c|c|c|c|c|c|}
\hline \multirow[b]{2}{*}{ № } & & \multirow[b]{2}{*}{$\begin{array}{c}\text { Варіант } \\
\text { відповіді }\end{array}$} & \multicolumn{2}{|c|}{ Відповіді медсестер } & \multicolumn{2}{|c|}{ Відповіді студентів } \\
\hline & & & $\begin{array}{c}\text { Абс. } \\
\text { кількість }\end{array}$ & Частка,\% & $\begin{array}{c}\text { Абс. } \\
\text { кількість }\end{array}$ & Частка,\% \\
\hline 001 & 5 & $\begin{array}{l}\text { форма } \\
\text { існування }\end{array}$ & 6 & 5 & 50 & 46 \\
\hline 002 & 3 & Всесвіт & 4 & 3 & 12 & 11 \\
\hline 003 & 6 & знання & 5 & 4 & 10 & 9 \\
\hline 004 & 2 & буття & 6 & 5 & 9 & 8 \\
\hline 005 & 1 & Божий дар & 88 & 80 & 29 & 26 \\
\hline 006 & 4 & ваш варіант & 1 & 1 & 0 & 0 \\
\hline & & Всього & 110 & 100,0 & 110 & 100,0 \\
\hline
\end{tabular}

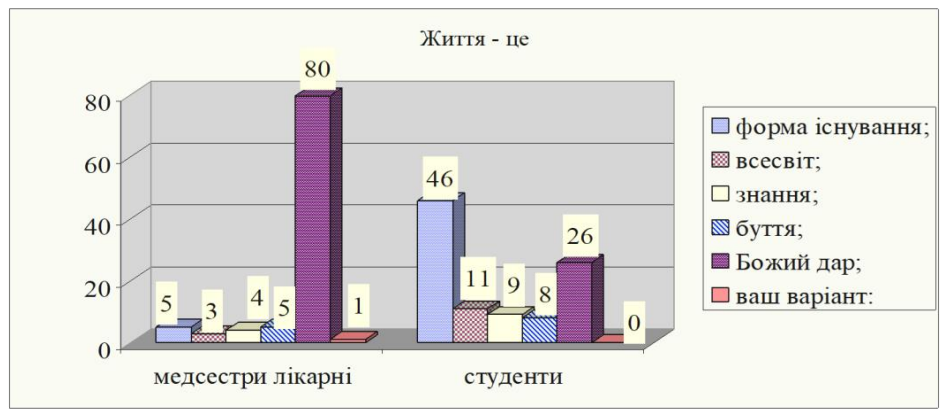

Рис. 2. Структура відповідей респондентів на питання № 1

Друге питання анкети, «Любити життя - це?», також спонукало респондентів до роздумів. Зокрема, левова частка працюючих медсестер (74 особи або 68\%) та лише 29 студентів або ж 26\% обрали відповідь - цінувати кожну хвилину свого життя. Вони вважають, що життя одне, безцінне, для кожного унікальне, неповторне, і, на жаль, скінченне, кожну мить життя потрібно цінувати. Цінувати життя та здоров'я обрали $5 \%$ медсестер та $11 \%$ студентів. Тоді як більшість студентів (42 особи або 38\%) і лише 6\% працюючих медсестер обрали варіант - кохати та посміхатися, відчувати себе щасливим. Таке різне трактування можна пояснити різницею у віку, життєвому досвіду. Якщо старші, працюючі респонденти вважають, що люди не повинні сприймати все як належне, а цінувати життя як дар Божий i усвідомлювати цінність свого здоров'я, як можливість вести якісне життя, то студенти вбачають у житті ті цінності, якими хотіли б його 
наділити, щоб відчувати себе щасливими. При цьому, 9\% працюючих медсестер і 8\% студентів вважають, що любити життя означає вміти прощати ворогам, оскільки, для психіки людини важливий характер емоцій, душевний комфорт. $17 \%$ студентів та $11 \%$ працюючих медсестер вважають, що це означає дорожити рідними людьми, які $\epsilon$ неповторною цінністю. Серед працюючих медсестер один респондент дав власне трактування: «Любити життя - це віддавати його, віддавати свій розум, свою силу, своє майно, свій час, одним словом, віддавати своє життя тим, кого ми любимо.

Таблиця 3

Питання 2. Любити життя - це? (Цінність любові до життя)

\begin{tabular}{|c|c|c|c|c|c|c|}
\hline \multirow{2}{*}{ № } & \multirow{2}{*}{ 音 } & \multirow{2}{*}{ Варіант відповіді } & \multicolumn{2}{|c|}{$\begin{array}{l}\text { Відповіді } \\
\text { медсестер }\end{array}$} & \multicolumn{2}{|c|}{$\begin{array}{l}\text { Відповіді } \\
\text { студентів }\end{array}$} \\
\hline & & & \begin{tabular}{|c|} 
Абс. \\
кількість
\end{tabular} & $\begin{array}{c}\text { Частка, } \\
\%\end{array}$ & $\begin{array}{c}\text { Абс. } \\
\text { кількість }\end{array}$ & $\begin{array}{c}\text { Частка, } \\
\%\end{array}$ \\
\hline 007 & 1 & $\begin{array}{l}\text { цінувати кожну хвилину } \\
\text { свого життя }\end{array}$ & 74 & 68 & 29 & 26 \\
\hline 008 & 3 & $\begin{array}{l}\text { кохати та посміхатися, } \\
\text { відчувати себе щасливим }\end{array}$ & 7 & 6 & 41 & 38 \\
\hline 009 & 4 & дорожити рідними людьми & 12 & 11 & 19 & 17 \\
\hline 010 & 5 & вміти прощати ворогам & 10 & 9 & 9 & 8 \\
\hline 011 & 2 & цінувати життя та здоров'я & 6 & 5 & 12 & 11 \\
\hline 012 & 6 & ваш варіант & 1 & 1 & 0 & 0 \\
\hline & & Всього & 110 & 100,0 & 110 & 100,0 \\
\hline
\end{tabular}

Любити життя - означає

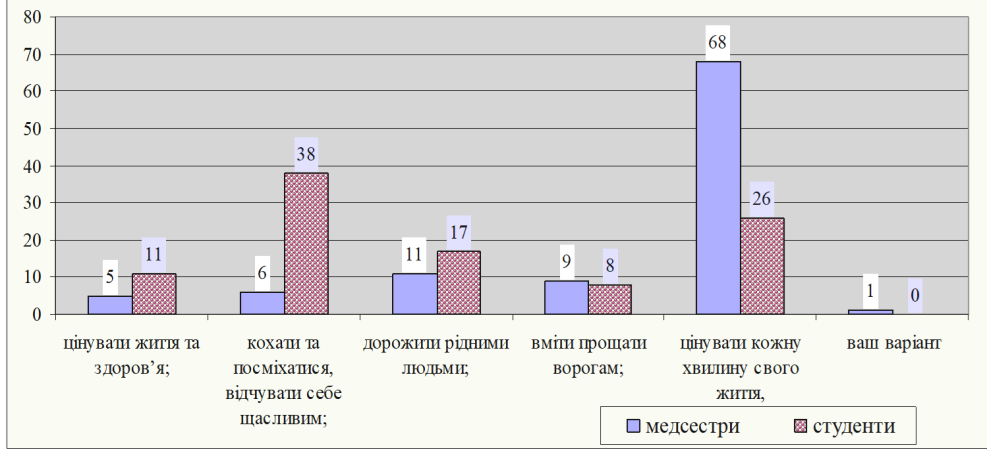

Рис. 3. Структура відповідей респондентів на питання № 2 
На питання, як респонденти розуміють поняття «гуманна людина», більшість опитаних - 68 працюючих медсестер або $62 \%$ та 49 студентів або 45\% відповіли, що це людина, яка здатна до благодійних вчинків. Здійснювати благодійну діяльність, означає думати не тільки про свої інтереси, але також співвідносити їх із потребами інших. Серед працюючих респондентів 9\% та студентів $15 \%$ вважають, що це ввічлива, культурна людина, яка контролює свої емоції. Адже цим людина виражає людяність. 12\% працюючих та 21\% медсестер-студентів відповіли, що гуманна людина - це справедлива і розсудлива людина.

Таблиця 4

Питання № 3. Що Ви розумієте під поняттям «гуманна людина»? (Цінність любові до життя)

\begin{tabular}{|c|c|c|c|c|c|c|}
\hline \multirow{2}{*}{ № } & \multirow{2}{*}{ 点 } & \multirow{2}{*}{ Варіант відповіді } & \multicolumn{2}{|c|}{$\begin{array}{c}\text { Відповіді } \\
\text { медсестер }\end{array}$} & \multicolumn{2}{|c|}{$\begin{array}{l}\text { Відповіді } \\
\text { студентів }\end{array}$} \\
\hline & & & \begin{tabular}{|c|} 
Абс. \\
кількість
\end{tabular} & $\begin{array}{c}\text { Частка, } \\
\%\end{array}$ & $\begin{array}{c}\text { Абс. } \\
\text { кількість }\end{array}$ & $\begin{array}{c}\text { Частка, } \\
\%\end{array}$ \\
\hline 013 & 6 & $\begin{array}{l}\text { це людина, яка } \\
\text { приймає розумні, } \\
\text { обдумані рішення }\end{array}$ & 0 & - & 6 & 5 \\
\hline 014 & 5 & $\begin{array}{l}\text { справедлива і } \\
\text { розсудлива людина }\end{array}$ & 14 & 12 & 23 & 21 \\
\hline 015 & 1 & $\begin{array}{l}\text { людина, яка здатна до } \\
\text { благодійних вчинків }\end{array}$ & 68 & 62 & 49 & 45 \\
\hline 016 & 2 & \begin{tabular}{|l|} 
це людина, яка \\
поважає інших людей
\end{tabular} & 13 & 12 & 15 & 14 \\
\hline 017 & 4 & $\begin{array}{l}\text { ввічлива, культурна } \\
\text { людина, яка } \\
\text { контролює свої емоції }\end{array}$ & 10 & 9 & 17 & 15 \\
\hline 018 & 3 & ваш варіант & 5 & 5 & 0 & 0 \\
\hline & & Всього & 110 & 100,0 & 110 & 100,0 \\
\hline
\end{tabular}

В той же час, 12\% і 14\% респондентів відповідно, відповіли, що гуманна людина $є$ людиною, яка поважає інших людей, тому що розвинуте почуття поваги до інших - одна з найважливіших людських рис, етичний принцип, який вимагає відношення до іншої людини як до особистості. 


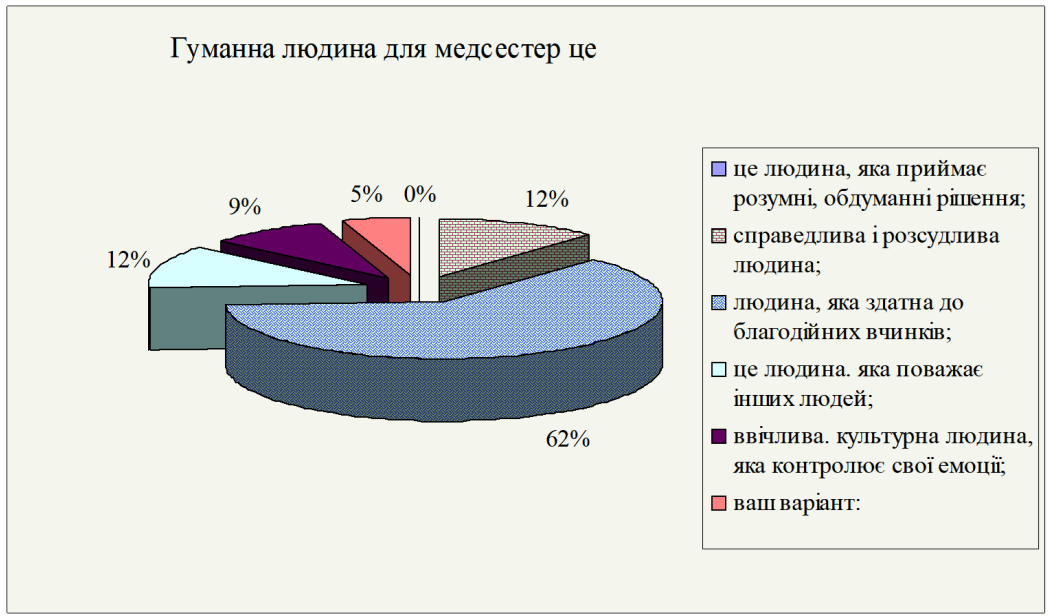

Рис. 4. а. Розмежована структура відповідей респондентів на питання № 3

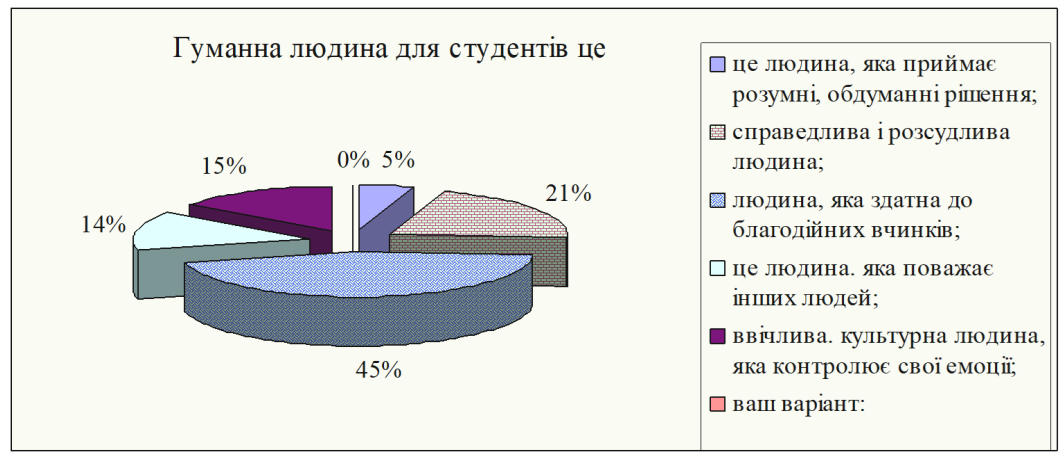

Рис. 4. б. Розмежована структура відповідей респондентів на питання № 3

Серед студентів 5\% опитаних вважають, що гуманність пов'язана з розумом, із здатністю приймати розумні, обдумані рішення, тоді як серед працюючих медсестер виявилося 5\% варіантів власних визначень. В основному вони зводяться до того, що це духовна людина, яка відчуває свою відповідальність за себе і за інших, вірить, що добро завжди перемагає зло, сама намагається робити добро. 
Таблиця 5

Питання № 4. Які скарги вам заважають вести повноцінне життя?

\begin{tabular}{|l|l|c|c|c|c|}
\hline \multirow{2}{*}{$№$} & \multirow{2}{*}{ Варіант відповіді } & \multicolumn{2}{|c|}{ Відповіді медсестер } & \multicolumn{2}{|c|}{ Відповіді студентів } \\
\cline { 3 - 6 } & $\begin{array}{c}\text { Абс. } \\
\text { кількість }\end{array}$ & $\begin{array}{c}\text { Частка, } \\
\mathbf{\%}\end{array}$ & $\begin{array}{c}\text { Абс. } \\
\text { кількість }\end{array}$ & $\begin{array}{c}\text { Частка, } \\
\mathbf{\%}\end{array}$ \\
\hline 019 & частий головний біль & 28 & 25 & 43 & 40 \\
\hline 020 & швидка втомлюваність & 20 & 18 & 37 & 34 \\
\hline 021 & проблеми з травленням & 11 & 10 & 19 & 17 \\
\hline 022 & біль в хребті & 26 & 24 & 2 & 1 \\
\hline 023 & неспокійний сон & 19 & 17 & 9 & 8 \\
\hline 024 & ваш варіант & 6 & 6 & 0 & 0 \\
\hline \multicolumn{2}{|r|}{ Всього } & 110 & 100,0 & 110 & 100,0 \\
\hline
\end{tabular}

Своєрідно також розподілилися відповіді респондентів щодо визначення скарг, які їм заважають вести повноцінне життя. Зокрема, відповіді працюючих респондентів розподілилися між варіантами майже пропорційно, тоді як $40 \%$ студентів (25\% працюючих медсестер) вказали на частий головний біль; $34 \%$ медсестерстудентів та $18 \%$ працюючих медсестер відмітили швидку втомлюваність. Проблеми з травленням мають $17 \%$ студентів та $10 \%$ працюючих медсестер. При цьому, біль у хребті відмітили $24 \%$ працюючих медсестер і лише 1\% медсестер-студентів. Практично вдвічі більше працюючих респондентів мають неспокійний сон (17\%), ніж опитаних студентів.

Таким чином, у порівняльній паралелі, підтверджуються попередні результати анкетування. Незмінним $\epsilon$ те, що студентський вік характеризується сприятливими умовами для психологічного, фізичного та соціального розвитку, також - це пора активної самооцінки. Студенти менше загострюють увагу на проблемах із здоров'ям, оскільки продовжують активно будувати своє життя по визначених цілях. В той же час, скарги на здоров'я $\epsilon$ більш наявними у дорослих жінок з медичною освітою, але їм ніколи хворіти, вони турбуються за інших: членів сім'ї, пацієнтів, колег.

На п'яте питання «Чи маєте ви хронічні захворювання?» відповіді розподілилися таким чином: 65\% працюючих медсестер дали ствердну відповідь, а 74\% студентів - заперечну. Слід відмітити, що відповідь «так» була більше наявна у анкетах, які заповнювали працюючі медсестри старшого віку (категорія 36-45 і більше років). 


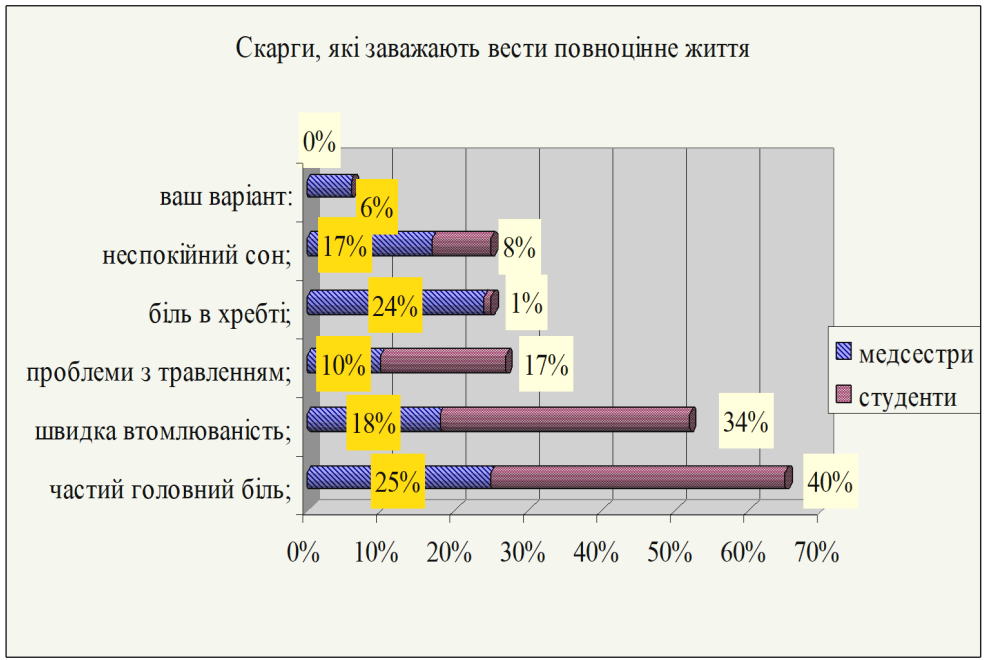

Рис. 5. Структура відповідей респондентів на питання № 4

Таблиця 6

Питання № 5. Чи маєте ви хронічні захворювання?

\begin{tabular}{|c|c|c|c|c|c|}
\hline \multirow[b]{2}{*}{ № } & \multirow[b]{2}{*}{ Варіант відповіді } & \multicolumn{2}{|c|}{ Відповіді медсестер } & \multicolumn{2}{|c|}{ Відповіді студентів } \\
\hline & & $\begin{array}{c}\text { Абс. } \\
\text { кількість }\end{array}$ & Частка,\% & $\begin{array}{c}\text { Абс. } \\
\text { кількість }\end{array}$ & Частка,\% \\
\hline 025 & так & 68 & 62 & 29 & 26 \\
\hline 026 & нi & 42 & 38 & 81 & 74 \\
\hline & Всього & 110 & 100,0 & 110 & 100,0 \\
\hline
\end{tabular}

Наявність хронічних захворювань

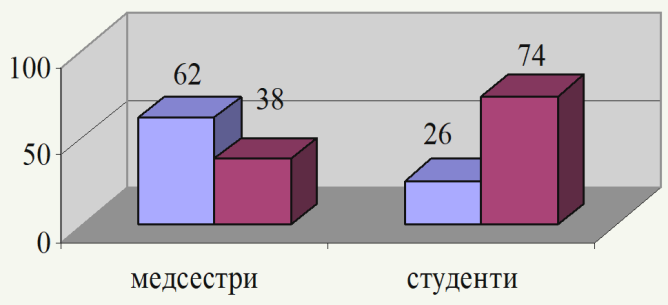

Рис. 6. Структура відповідей респондентів на питання № 5 
Отже, можемо зробити висновок, що психо-фізичний стан практикуючих медичних сестер через збільшення хронічних захворювань може впливати на їхню професійну культуру і професійне вигорання.

Практично будь-яка людина під час хвороби страждає. На питання «Як людина скоріше оцінює поняття «життя» під час хвороби?» були отримані такі результати: найбільша частка (69 особи або 63\%) працюючих респондентів та помірна частка студентів (20 особи або $19 \%)$ вважають, що людина нарешті усвідомлює, що для неї $€$ важливим насправді. Адже, для людей старшого віку «хвороба» - це період в житті, коли вони замислюються над сенсом свого буття, над прожитим і майбутнім і що $є$ що.

При цьому, більша частина (33 особи або 30\%) студентів та помірна частина працюючих медсестер (8 особи або 7\%) вважають, що має відбуватися боротьба за кожну хвилину життя, бо життя найвища цінність людини. А 30\% інших студентів та 19\% медсестер вважають, що людина усвідомлює, що ще багато залишилося непізнаним. Багато людей починають розуміти, що життя не вічне. Після таких роздумів більшість починає бачити навколишній світ (людей та все що їх оточує) з іншого ракурсу.

У порівняльній паралелі, тільки підтверджуються попередні результати анкетування.

Таблиця 7

Питання № 6. Як, на вашу думка, людина скоріше оцінює поняття «життя» під час хвороби?

\begin{tabular}{|c|c|c|c|c|c|c|}
\hline \multirow{2}{*}{ № } & \multirow{2}{*}{ 点 } & \multirow{2}{*}{ Варіант відповіді } & \multicolumn{2}{|c|}{$\begin{array}{c}\text { Відповіді } \\
\text { медсестер }\end{array}$} & \multicolumn{2}{|c|}{$\begin{array}{l}\text { Відповіді } \\
\text { студентів }\end{array}$} \\
\hline & & & \begin{tabular}{|c|} 
Абс. \\
кількість
\end{tabular} & $\begin{array}{c}\text { Частка } \\
\% \\
\end{array}$ & $\begin{array}{c}\text { Абс. } \\
\text { кількість }\end{array}$ & $\begin{array}{c}\text { Частка, } \\
\%\end{array}$ \\
\hline 027 & 2 & $\begin{array}{l}\text { має відбуватися боротьба за } \\
\text { кожну хвилину життя }\end{array}$ & 8 & 7 & 33 & 30 \\
\hline 028 & 6 & $\begin{array}{l}\text { потрібно жити одним } \\
\text { моментом }\end{array}$ & 12 & 11 & 10 & 9 \\
\hline 029 & 1 & $\begin{array}{l}\text { нарешті усвідомлює, що для } \\
\text { неї є важливим насправді }\end{array}$ & 69 & 63 & 20 & 18 \\
\hline 030 & 3 & $\begin{array}{l}\text { усвідомлює, що ще багато } \\
\text { залишилося непізнаним }\end{array}$ & 21 & 19 & 33 & 30 \\
\hline 031 & 5 & $\begin{array}{l}\text { життя використано сповна, } \\
\text { думки лише про життя після } \\
\text { смерті }\end{array}$ & 0 & 0 & 14 & 13 \\
\hline 032 & 4 & ваш варіант & 0 & 0 & 0 & 0 \\
\hline & & Всього & 110 & 100,0 & 110 & 100,0 \\
\hline
\end{tabular}


Оцінка поняття "життя" під час хвороби

життя використано сповна, думки лише про життя після смерті;

усвідомлює, що ще багато залишилося непізнаним;

нарешті усвідомлює, що для неї $\epsilon$ важливим насправді;

потрібно жити одним моментом;

має відбуватися боротьба за кожну хвилину життя;

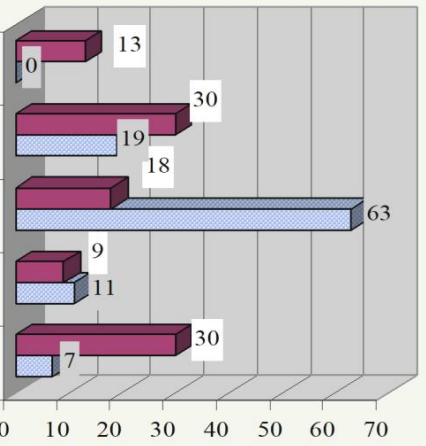

$\square$ студенти

$\square$ медсестри

\section{Рис. 7. Структура відповідей респондентів на питання № 6}

У сучасному житті стреси відіграють значну роль. Стрес - це напружений стан організму людини, як фізичний, так і психічний. В рамках даного дослідження з'ясовувалося, що $\epsilon$ найбільшим стресом для медиків різних вікових категорій.

За обробленими даними, що видається логічним, найбільшим стресом для більшої частини усіх опитуваних, а саме 97 осіб (або 88\%) віком 36-45 і більше років працюючих медсестер та 75 осіб (або $68 \%$ ) віком до 20 років є смерть близької людини. Адже, передати стан людини яка втратила близьку людину неможливо. Нестерпний біль, нерозуміння світу, заперечення всього, навіть байдужість до життя, повна відсутність віри у щасливе майбутнє. При цьому, 13 осіб або 12\% працюючих медсестер вбачають більш стресовою ситуацію - звільнення 3 роботи. Зауважимо, що такий варіант відповіді обрала вікова категорія 21-25 років. Можна припустити, що вони ще не переживали втрати близької людини, або без роботи залишаться без засобів проживання, що розглядається подібно 
смерті. Серед студентів - це вік 18-20 років ще 29 осіб або 26\% обрали варіант - зрада (ніби навмисне приниження) коханої людини. Погодимося, що наслідками зради є дуже негативні емоції, небажання жити, депресії, але слід знати, що найгірша зрада - то зрада самого себе, своїх поглядів та бажань. Ще 6 осіб (або 4\%) студентів вбачають найбільш стресовим для ним - звільнення 3 навчального закладу.

Таблиця 8

Питання № 7. Що для Вас є найбільшим стресом

(виберіть одну відповідь)?

\begin{tabular}{|l|l|c|c|c|c|}
\hline \multirow{2}{*}{ № } & Варіант відповіді & \multicolumn{2}{|c|}{ Відповіді медсестер } & \multicolumn{2}{c|}{ Відповіді студентів } \\
\cline { 3 - 6 } & $\begin{array}{c}\text { Абс. } \\
\text { кількість }\end{array}$ & Частка,\% & $\begin{array}{c}\text { Абс. } \\
\text { кількість }\end{array}$ & Частка,\% \\
\hline 033 & звільнення з роботи & 13 & 12 & 0 & 0 \\
\hline 034 & $\begin{array}{l}\text { звільнення 3 } \\
\text { навчального закладу }\end{array}$ & 0 & 0 & 6 & 4 \\
\hline 035 & академічна відпустка & 0 & 0 & 0 & 0 \\
\hline 036 & $\begin{array}{l}\text { смерть близької } \\
\text { людини }\end{array}$ & 97 & 88 & 75 & 68 \\
\hline 037 & $\begin{array}{l}\text { зрада коханої } \\
\text { людини }\end{array}$ & 0 & 0 & 29 & 26 \\
\hline 038 & ваш варіант & 0 & 0 & 0 & 0 \\
\hline \multicolumn{2}{|c|}{ Всього } & 110 & 100,0 & 110 & 100,0 \\
\hline
\end{tabular}

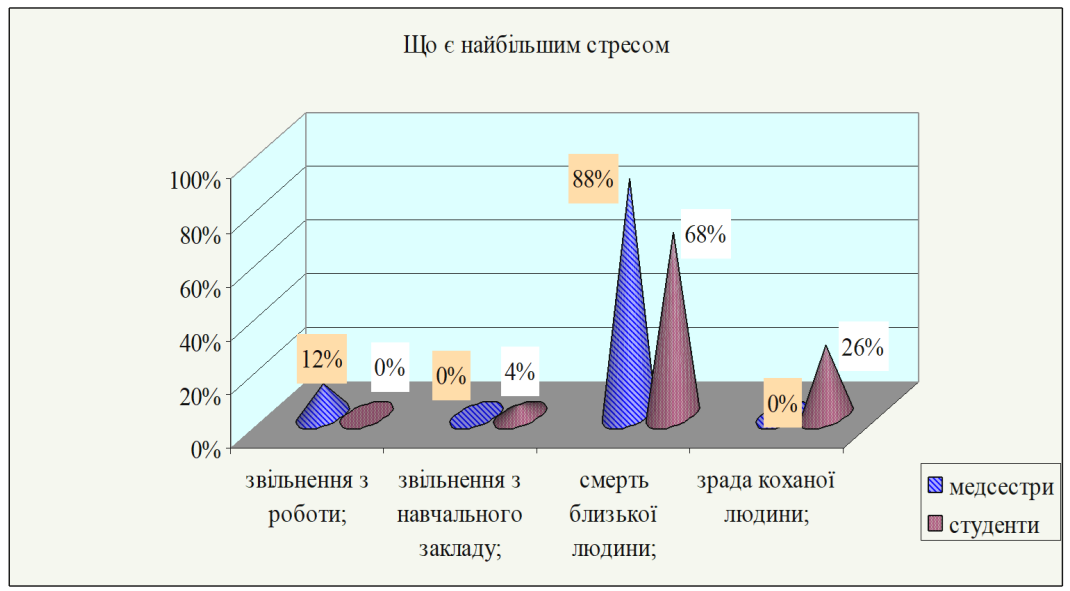

Рис. 8. Структура відповідей респондентів на питання № 7 
Наступне питання анкети було поставлено з метою виявлення рівня стресостійкості, дратівливості респондентів, а саме, що вони зроблять, якщо сусіди після одинадцятої вечора увімкнуть голосно телевізор. Так більшість опитаних в рівній частці в обох вибірках (по $80 \%$ ) буде намагатися заснути, переборюючи гнів, що демонструє високий рівень терпіння респондентів та толерантності.

Таблиця 9

Питання № 8. Що Ви зробите, якщо ваші сусіди після одинадцятої вечора вмикають голосно телевізор? (Соціальні цінності)

\begin{tabular}{|c|l|c|c|c|c|}
\hline \multirow{2}{*}{ № } & \multirow{2}{*}{ Варіант відповіді } & \multicolumn{2}{|c|}{ Відповіді медсестер } & \multicolumn{2}{|c|}{ Відповіді студентів } \\
\cline { 3 - 6 } & $\begin{array}{c}\text { Абс. } \\
\text { кількість }\end{array}$ & $\begin{array}{c}\text { Частка, } \\
\text { \% }\end{array}$ & $\begin{array}{c}\text { Абс. } \\
\text { кількість }\end{array}$ & $\begin{array}{c}\text { Частка, } \\
\text { \% }\end{array}$ \\
\hline 040 & $\begin{array}{l}\text { намагаєтеся заснути, } \\
\text { переборюючи гнів }\end{array}$ & 86 & 79 & 87 & 80 \\
\hline 041 & $\begin{array}{l}\text { вмете до сусідів } \\
\text { свій телевізор голосно }\end{array}$ & 10 & 9 & 0 & 0 \\
\hline 042 & викликаєте міліцію & 0 & 1 & 23 & 20 \\
\hline 043 & ваш варіант & 12 & 11 & 0 & 0 \\
\hline \multicolumn{2}{|}{ Всього } & 110 & 100,0 & 110 & 100,0 \\
\hline
\end{tabular}

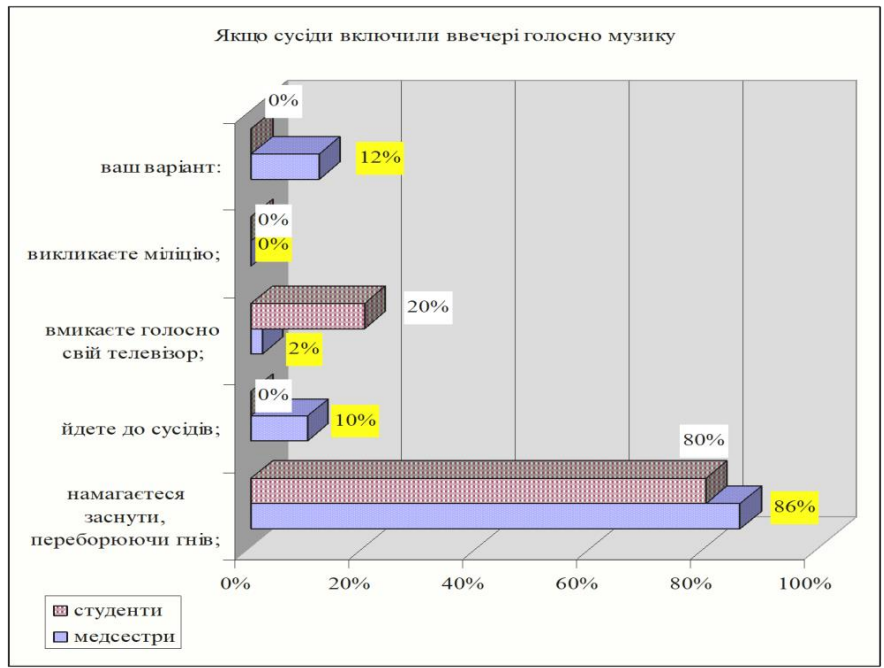

Рис. 9. Структура відповідей респондентів на питання № 8 
Зрештою, 20\% молодих студентів, поважаючих свої права, таки увімкне голосно свій телевізор, щоб сусіди відразу зрозуміли свою помилку. Це зробить і 1\% працюючих медсестер, ще $9 \%$ найстарших працюючих медсестер (вік 50 і більше років) піде до сусідів, щоб нагадати про нормативні і моральні правила проживання. А 11\% працюючих медсестер додали свої варіанти відповідей, які практично всі звелися до поради: жити у приватному будинку, щоб не мати таких проблем із сусідами.

Замислитися і обрати варіант відповіді змусило респондентів запитання анкети «що $\epsilon$ для них найбільшою цінністю?». В результаті, обидві вибірки в більших частках (78\% працюючі медсестри і 59\% студентів) обрали варіант «життя», яким би воно не було. Ще 8\% працюючих респондентів та 5\% студентів обрали варіант «здоров'я», як найбільше багатство у житті людини. В той же час, $14 \%$ студентської молоді та $8 \%$ медсестер вважають, що цінністю є друзі. Решта опитаних (6\% серед працюючих медсестер та $23 \%$ серед студентів визначили власні варіанти відповідей. Зокрема, серед відповідей працюючих медсестер прослідковується підміна понять: замість обрати гуманізм (співчуття), зустрічалися подібні, які замінюють філософський i етико-соціологічний принцип відношення до людини як до вищої цінності: $є$ куди і до кого повертатись; сім'я, діти; розуміння; віра; людяність.

Таблиця 10

\section{Питання № 9. Що є для Вас найбільшою цінністю?}

\begin{tabular}{|c|c|c|c|c|c|c|}
\hline \multirow{2}{*}{ № } & \multirow{2}{*}{ 离 } & \multirow{2}{*}{ Варіант відповіді } & \multicolumn{2}{|c|}{$\begin{array}{l}\text { Відповіді } \\
\text { медсестер }\end{array}$} & \multicolumn{2}{|c|}{$\begin{array}{l}\text { Відповіді } \\
\text { студентів }\end{array}$} \\
\hline & & & $\begin{array}{c}\text { Абс. } \\
\text { кількість }\end{array}$ & Частка,\% & $\begin{array}{c}\text { Абс. } \\
\text { кількість }\end{array}$ & Частка,\% \\
\hline 044 & 1 & життя & 85 & 78 & 64 & 59 \\
\hline 045 & 2 & здоров'я & 9 & 8 & 6 & 5 \\
\hline 046 & 6 & гроші & 0 & 0 & 0 & 0 \\
\hline 047 & 3 & друзі & 9 & 8 & 15 & 14 \\
\hline 048 & 5 & гуманізм(співчуття) & 0 & 0 & 0 & 0 \\
\hline 000 & 4 & ваш варіант & 7 & 6 & 25 & 23 \\
\hline & & Всього & 110 & 100,0 & 110 & 100,0 \\
\hline
\end{tabular}

Студенти у власних варіантах ще вказували на свободу у виборі, любов, спілкування, духовність. Це говорить про те, що сутність поняття «гуманізм» кожен розуміє по-своєму, але довільні відповіді вказують на нього. 


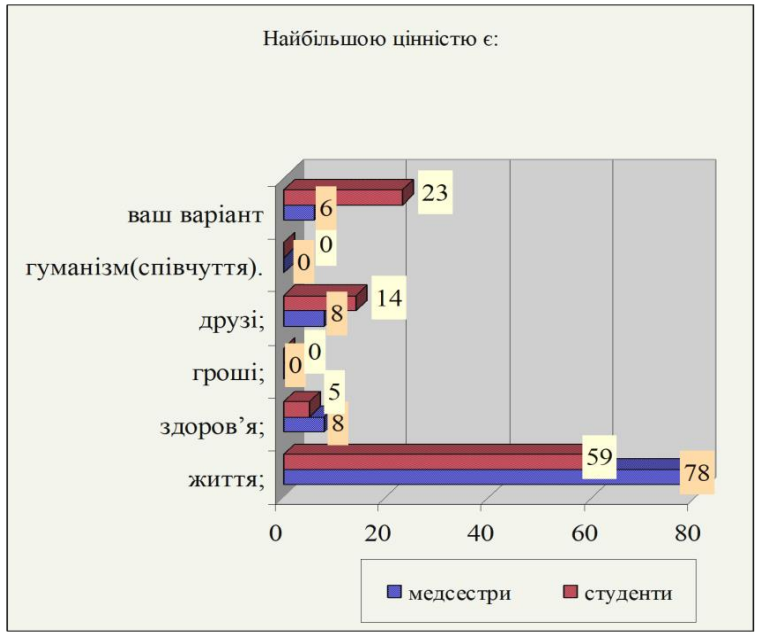

\section{Рис. 10. Структура відповідей респондентів на питання № 9}

На наступне питання «яка професія найбільш престижна в сучасному українському суспільстві?» відповіді респондентів розподілилися таким чином: найбільша частка працюючих медсестер (27\%) вказала на варіант «менеджер», такий же варіант обрали $32 \%$ студентів. Професію «бізнесмен» виділила така ж частка студентів (32\%) та 18\% працюючих медсестер. Практично однакові частки в обох вибірках (19\% і 18\%) обрали таки варіант «медсестра».

Таблиця 11

Питання № 10. Виберіть яка професія найбільш престижна в сучасному українському суспільстві? (Соціальні ідеали)

\begin{tabular}{|c|c|c|c|c|c|c|}
\hline \multirow{2}{*}{ № } & \multirow{2}{*}{$\stackrel{\pi}{\pi}$} & \multirow{2}{*}{ Варіант відповіді } & \multicolumn{2}{|c|}{$\begin{array}{c}\text { Відповіді } \\
\text { медсестер }\end{array}$} & \multicolumn{2}{|c|}{ Відповіді студентів } \\
\hline & & & $\begin{array}{c}\text { Абс. } \\
\text { кількість }\end{array}$ & $\begin{array}{c}\text { Частка, } \\
\%\end{array}$ & $\begin{array}{c}\text { Абс. } \\
\text { кількість }\end{array}$ & $\begin{array}{c}\text { Частка, } \\
\%\end{array}$ \\
\hline 049 & 3 & бізнесмен & 20 & 18 & 35 & 32 \\
\hline 050 & 1 & медична сестра & 21 & 19 & 20 & 18 \\
\hline 051 & 4 & викладач & 20 & 18 & 12 & 11 \\
\hline 052 & 2 & менеджер & 29 & 27 & 35 & 32 \\
\hline 053 & 5 & $\begin{array}{l}\text { власник фермерського } \\
\text { господарства }\end{array}$ & 17 & 15 & 8 & 7 \\
\hline 054 & 6 & ваш варіант & 3 & 3 & 0 & 0 \\
\hline & & Всього & 110 & 100,0 & 110 & 100,0 \\
\hline
\end{tabular}




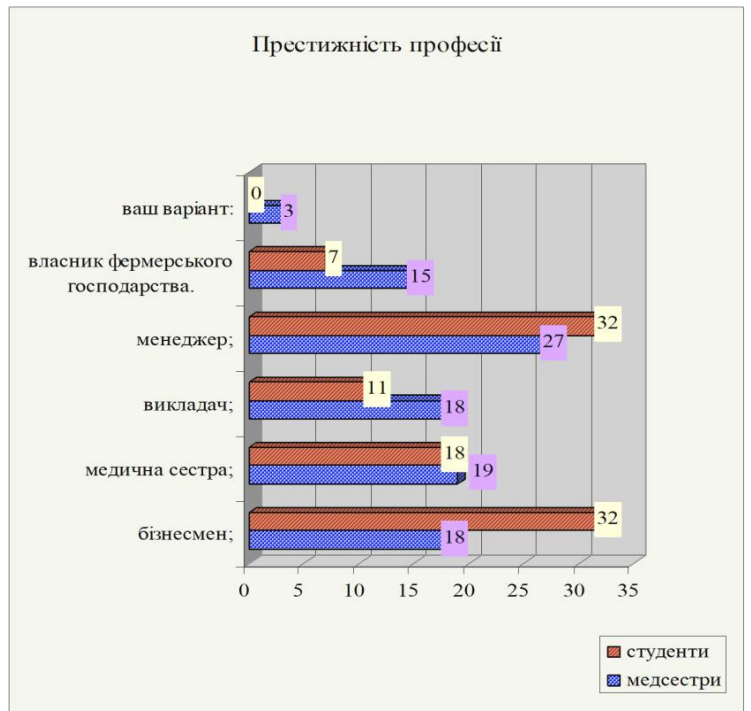

Рис. 11. Структура відповідей респондентів на питання № 10

Невисока частка медичних сестер старших за віком (18\%) та $11 \%$ студентів обрали варіант «викладач». Менша частка медсестер (15\%) та лише $7 \%$ студентів віддали перевагу «власнику фермерського господарства. Такий розподіл обгрунтовується низьким рівнем матеріальної i нематеріальної мотивації до продуктивної і благородної праці в ЛПЗ при високому рівні наявного емоційного вигоряння, впливу шкідливих факторів виробничого середовища. При цьому, у $3 \%$ власних варіантів працюючих медсестер ще вказувалося на професію «банкір», «юрист», «адміністратор автоматизованих систем».

Оскільки, опитувані вже пов'язані з медсестринським фахом, в рамках даного дослідження їм було запропоновано питання: «які вміння і навички $\epsilon$ найважливішими для роботи медичної сестри?». 


\section{Питання № 11. Які вміння і навички Ви вважаєте} найважливішими для роботи медичної сестри?

\section{(Пробесійні навички та вміння)}

\begin{tabular}{|c|c|c|c|c|c|c|}
\hline \multirow{2}{*}{ № } & \multirow{2}{*}{ Е } & \multirow{2}{*}{ Варіант відповіді } & \multicolumn{2}{|c|}{$\begin{array}{c}\text { Відповіді } \\
\text { медсестер }\end{array}$} & \multicolumn{2}{|c|}{$\begin{array}{l}\text { Відповіді } \\
\text { студентів }\end{array}$} \\
\hline & & & $\begin{array}{c}\text { Абс. } \\
\text { кількість }\end{array}$ & Частка,\% & \begin{tabular}{|c|} 
Абс. \\
кількість
\end{tabular} & Частка,\% \\
\hline 055 & 3 & рухові (мануальні) & 20 & 18 & 8 & 7 \\
\hline 056 & 1 & $\begin{array}{l}\text { перцептивні (чуттєве } \\
\text { сприйняття) }\end{array}$ & 61 & 56 & 44 & 40 \\
\hline 057 & 4 & $\begin{array}{l}\text { інтелектуальні } \\
\text { (інструментально- } \\
\text { розрахункові) }\end{array}$ & 8 & 7 & 25 & 23 \\
\hline 058 & 2 & клінічні & 21 & 19 & 33 & 30 \\
\hline 059 & 6 & рахувати гроші & 0 & 0 & 0 & 0 \\
\hline 060 & 5 & ваш варіант & 0 & 0 & 0 & 0 \\
\hline & & Всього & 110 & 100,0 & 110 & 100,0 \\
\hline
\end{tabular}

В медсестри мають бути вміння та навички

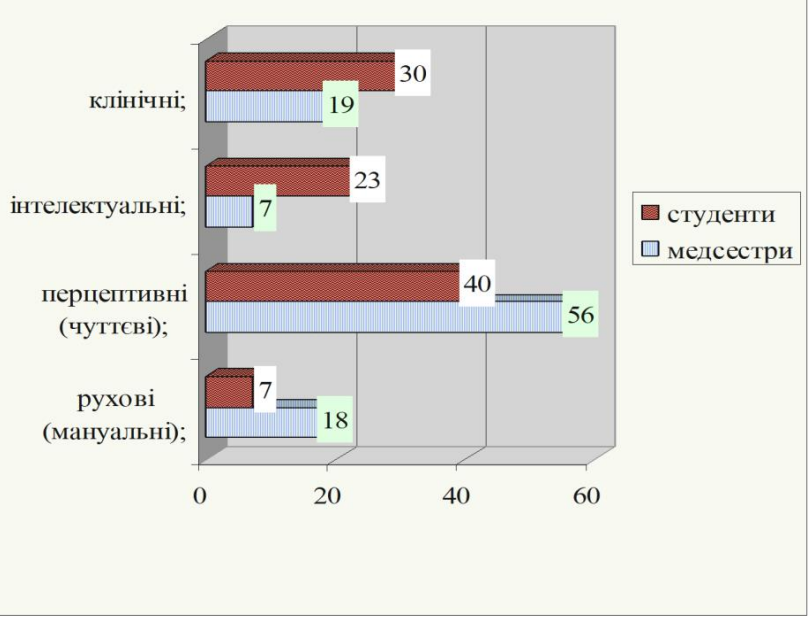

Рис. 12. Структура відповідей респондентів на питання № 11 
Відповіді на нього розподілилися таким чином: працюючі медсестри в більшості - 56\% та $40 \%$ студентів обрали перцептивні (чуттєві сприйняття). Адже, саме такого роду навички дозволяють їм в процесі виконання функціональних обов'язків правильно сприймати оточуючих, в першу чергу, пацієнта, колег; проявляти емпатію, розуміти ці переживання. При цьому, значна частина студентської молоді (30\%) і працюючих медсестер (19\%) обрали варіант «клінічні». Це, мабуть, пов'язано з особливістю навчального процесу, орієнтацією студентів на вирішення професійних (клінічних) задач, а в працюючих медсестер - 3 конкретизацією цих клінічних задач (робота медсестри в різних закладах, відділеннях має свою специфіку). 23\% опитаних студентів і 7\% працюючих медсестер виділили інтелектуальні (інструментально-розрахункові) навички, оскільки вважають, що НТП швидко впроваджується в медичну галузь, необхідно вміти користуватися складним обладнанням, здійснювати певного роду розрахунки. А на думку $18 \%$ медсестер та 7\% студентів важливими виявилися рухові (мануальні) навички. Вони, мабуть, мали на увазі ті, що необхідні медсестрі для виконання обов'язків: робити ін'єкції, накладати пов'язки тощо.

Логічним продовженням опитування стало питання «чи потрібно медичній сестрі розвивати в собі вміння безперечно виконувати вказівки лікаря?» У підсумку з'ясувалося, що абсолютна більшість респондентів з студентської вибірки (90\%) дали ствердну відповідь, адже їх вчать, що медична сестра в процесі виконання професійних функцій покликана виконувати саме вказівки лікаря і повідомляти йому результати свого спостереження за хворим. Разом з тим, так вважають не всі, а саме 65\% опитаних працюючих медсестер. При цьому $5 \%$ опитаних студентів обрали заперечну відповідь. Крім того досвід роботи медсестер в ЛПЗ 5 і більше років (вікова група 45 i більше років) дозволив визначили власний варіант відповіді на запитання (35\%). Те ж саме зробили 5\% опитаних студентів. Узагальнено ці відповіді містять твердження: вказівки лікаря - це лише вказівки щодо лікувальних маніпуляцій, частина роботи, а медсестра має ще створити сприятливу атмосферу у відділенні, ввійти в довіру до хворого, «оточити його любов'ю і розумною утіхою (за Гіппократом), виконати іншу роботу, яка не потребує вказівок. Тобто можна зробити висновки, що у медичних сестер, які вже мають практичні навички роботи більше засвоєно ази професійної діяльності, в т.ч. етики і деонтології. 
Таблиця 13

Питання № 12. Чи потрібно медичній сестрі розвивати в собі вміння безперечно виконувати вказівки лікаря?

(Норми взаємодії з керівництвом)

\begin{tabular}{|c|c|l|c|c|c|c|}
\hline \multirow{2}{*}{ № } & \multirow{2}{*}{\begin{tabular}{c}
\multirow{2}{*}{$\begin{array}{c}\text { Варіант } \\
\text { відповіді }\end{array}$} \\
\cline { 3 - 7 }
\end{tabular}} & $\begin{array}{c}\text { Відповіді медсестер } \\
\text { кількість }\end{array}$ & \multicolumn{2}{|c|}{ Частка,\% } & $\begin{array}{c}\text { Абс. } \\
\text { кількість }\end{array}$ & Частка,\% \\
\hline 061 & 1 & так & 72 & 65 & 100 & 90 \\
\hline 062 & 3 & ні & 0 & 0 & 5 & 5 \\
\hline 063 & 2 & ваш варіант & 38 & 35 & 5 & 5 \\
\hline \multicolumn{2}{|c|}{ Всього } & 110 & 100,0 & 110 & 100,0 \\
\hline
\end{tabular}

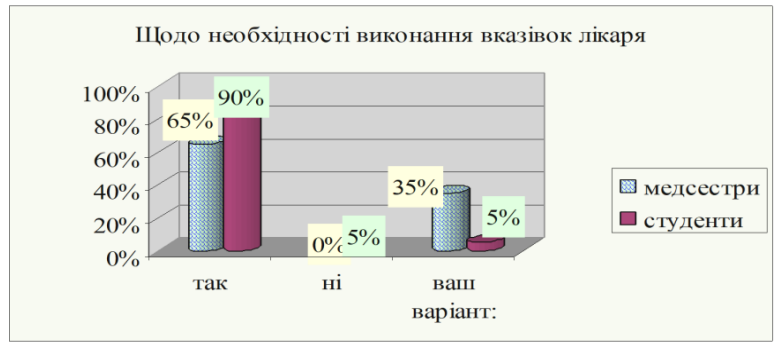

Рис. 13. Структура відповідей респондентів на питання № 12

Наступне питання: «чи є важливою духовна (релігійна) цінність в професії медичної сестри?» виявилося досить складним для респондентів. Адже, в суспільстві підтримується думка, що особистість медичної сестри - це органічний сплав високих моральних якостей, вона ніколи, навіть під загрозою, в т.ч. власних релігійних переконань, не повинна використовувати медичні знання в збиток нормам гуманності. При цьому, віросповідання медсестер $є$ неоднорідним. За опрацьованими результатами 45\% працюючих медсестер та 20\% студентів дали ствердну відповідь, адже, згідно 3 постулатами релігійної етики, людина має бути милосердною заради блага й спасіння власної душі. Філософські роздуми змусили 23\% працюючих медсестер та $32 \%$ студентів дати заперечну відповідь. А ще частина опитуваних (32\% працюючих медсестер та більшість - 48\% студентів) обрали варіант відповіді «вагаюся відповісти». Це, на нашу думку, свідчить про недостатні знання щодо духовних цінностей людини, медичної етики та її релігійної складової, що може негативно позначитися на формуванні професійної культури працюючих i майбутніх медичних сестер. 


\section{Питання № 13. Чи є важливою духовна (релігійна) цінність}

Таблиця 14 в професії медичної сестри? (Духовні цінності)

\begin{tabular}{|c|c|c|c|c|c|c|}
\hline \multirow[b]{2}{*}{ № } & \multirow[b]{2}{*}{ 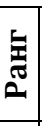 } & \multirow[b]{2}{*}{ Варіант відповіді } & \multicolumn{2}{|c|}{ Відповіді медсестер } & \multicolumn{2}{|c|}{ Відповіді студентів } \\
\hline & & & $\begin{array}{c}\text { Абс. } \\
\text { кількість }\end{array}$ & Частка,\% & $\begin{array}{c}\text { Абс. } \\
\text { кількість }\end{array}$ & Частка,\% \\
\hline 064 & 1 & так & 50 & 45 & 22 & 20 \\
\hline 065 & 3 & $\mathrm{Hi}$ & 25 & 23 & 35 & 32 \\
\hline 066 & 2 & $\begin{array}{l}\text { вагаюся } \\
\text { відповісти }\end{array}$ & 35 & 32 & 53 & 48 \\
\hline & & Всього & 110 & 100,0 & 110 & 100,0 \\
\hline
\end{tabular}

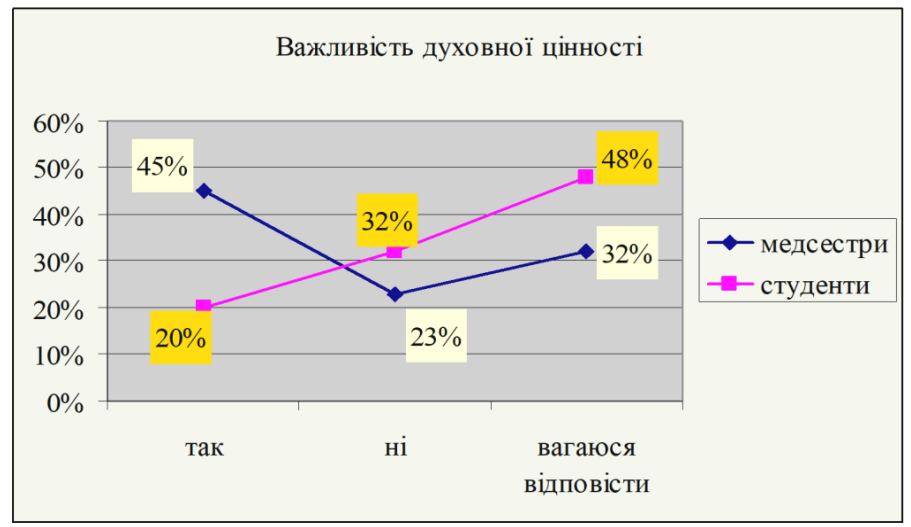

Рис. 14. Структура відповідей респондентів на питання № 13

В свою чергу, це вказує на актуальність піднятої у дослідженні проблему, необхідності інформаційного впливу на вже існуючий у ЛПЗ та навчальних циклах процес формуванні медичної професійної культури, відповідних цінностей, які мусять інтегруватися із суспільними. На нашу думку, особисті якості медичного працівника повинні характеризуватися безпосередністю, переживанням, душевністю, об'єктивністю, чутливістю, сприятливістю. На думку все ж вагомої частки (36\%) опитуваний медичних сестер, які вже працюють за фахом та медсестер-студентів (28\%) - це емпатія та милосердя. Адже, медсестра має перейматися почуттями та переживаннями пацієнта та прагнути допомогти йому. В свою чергу, милосердя грунтується на таких якостях, як чуйність, уважність, доброзичливість і несумісне з пихою, байдужістю, брутальністю. 
Питання № 14. Які особисті якості мають бути у медичної сестри? (Особисті якості)

\begin{tabular}{|c|c|c|c|c|c|c|}
\hline \multirow{2}{*}{ № } & \multirow{2}{*}{ 离 } & \multirow{2}{*}{ Варіант відповіді } & \multicolumn{2}{|c|}{$\begin{array}{l}\text { Відповіді } \\
\text { медсестер }\end{array}$} & \multicolumn{2}{|c|}{$\begin{array}{l}\text { Відповіді } \\
\text { студентів }\end{array}$} \\
\hline & & & \begin{tabular}{|c|} 
Абс. \\
кількість
\end{tabular} & Частка,\% & $\begin{array}{c}\text { Абс. } \\
\text { кількість }\end{array}$ & Частка,\% \\
\hline 067 & 1 & $\begin{array}{l}\text { емпатія та } \\
\text { милосердя }\end{array}$ & 38 & 36 & 31 & 28 \\
\hline 068 & 7 & $\begin{array}{c}\text { впевненість в собі, } \\
\text { наполегливість }\end{array}$ & 9 & 7 & 2 & 2 \\
\hline 069 & 6 & принциповість & 15 & 14 & 2 & 2 \\
\hline 070 & 2 & уважність & 31 & 28 & 21 & 19 \\
\hline 071 & 4 & охайність & 4 & 4 & 18 & 16 \\
\hline 072 & 8 & терпеливість & 2 & 2 & 4 & 4 \\
\hline 073 & 3 & чесність & 1 & 1 & 19 & 17 \\
\hline 074 & 5 & доброта & 10 & 8 & 13 & 12 \\
\hline \multicolumn{3}{|r|}{ Всього } & 110 & 100,0 & 110 & 100,0 \\
\hline
\end{tabular}

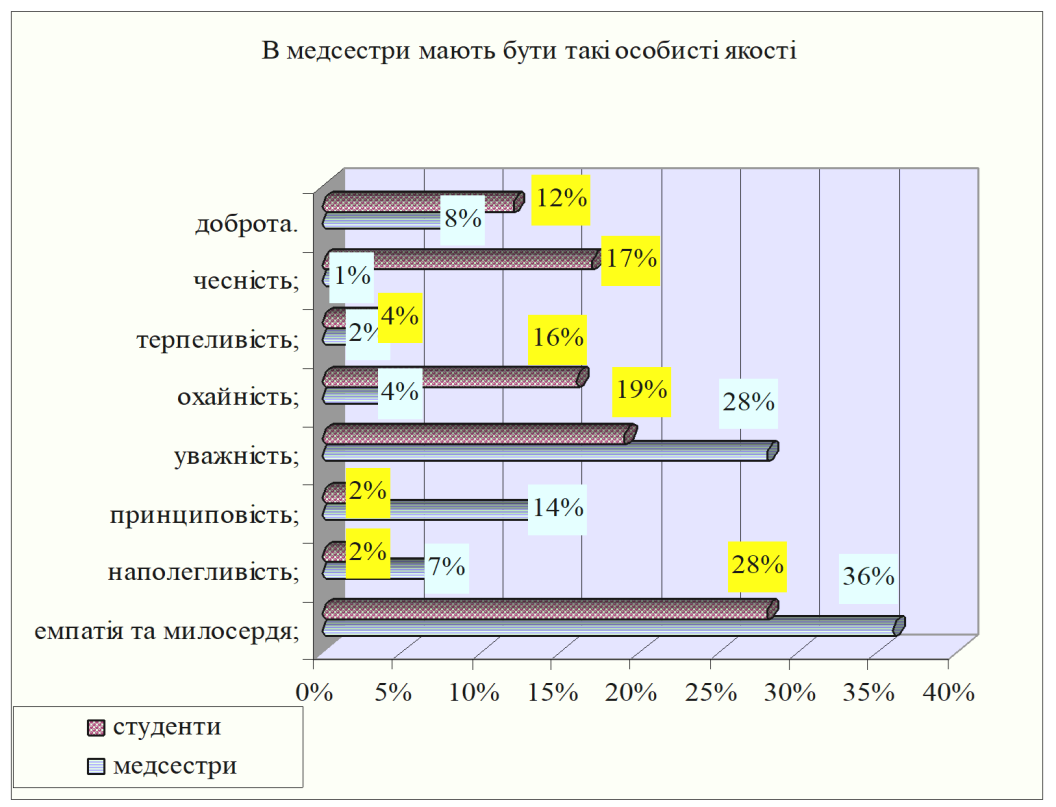

Рис. 15. Структура відповідей респондентів на питання № 14 
При цьому, 28\% опитаних працюючих медсестер та 19\% медсестер-студентів окремо виділили варіант «уважність», оскільки, це важлива умова чуттєвого й раціонального відображення дійсності, логічного ходу думки та іï позитивних результатів медсестринської роботи. Тоді як $17 \%$ медсестер-студентів та $1 \%$ працюючих медсестер обрали варіант «чесність» як одну з основних граней людських чеснот, моральну якість, що відображає важливу вимогу моральності.

Професія медсестри передбачає, насамперед, любов до своєї праці, любов до хворої людини та професійну майстерність. На питання «які професійні якості мають бути у медичної сестри?» однакова кількість опитаних в обох вибірках (32\%) обрали варіант «професійна компетентність».

Таблиця 16

Питання № 15. Які професійні якості мають бути у медичної сестри? (Стандарти поведінки)

\begin{tabular}{|c|c|c|c|c|c|c|}
\hline \multirow{2}{*}{ № } & \multirow{2}{*}{ 完 } & \multirow{2}{*}{ Варіант відповіді } & \multicolumn{2}{|c|}{$\begin{array}{l}\text { Відповіді } \\
\text { медсестер }\end{array}$} & \multicolumn{2}{|c|}{$\begin{array}{l}\text { Відповіді } \\
\text { студентів }\end{array}$} \\
\hline & & & \begin{tabular}{|c|} 
Абс. \\
кількість
\end{tabular} & Частка,\% & $\begin{array}{c}\text { Абс. } \\
\text { кількість }\end{array}$ & Частка,\% \\
\hline 075 & 7 & $\begin{array}{l}\text { захоплення своєю } \\
\text { роботою }\end{array}$ & 7 & 6 & 9 & 8 \\
\hline 076 & 1 & $\begin{array}{l}\text { професійна } \\
\text { компетентність }\end{array}$ & 34 & 32 & 34 & 32 \\
\hline 077 & 8 & $\begin{array}{l}\text { готовність до } \\
\text { самопожертви }\end{array}$ & 2 & 2 & 6 & 5 \\
\hline 078 & 2 & $\begin{array}{l}\text { бездоганне } \\
\text { виконання своїх } \\
\text { обов'язків }\end{array}$ & 21 & 19 & 22 & 20 \\
\hline 079 & 4 & $\begin{array}{l}\text { професійна рішучість } \\
\text { і відповідальність }\end{array}$ & 15 & 13 & 17 & 15 \\
\hline 080 & 3 & уважність та інтуїція & 18 & 16 & 11 & 10 \\
\hline 081 & 5 & $\begin{array}{l}\text { повага до пацієнта і } \\
\text { його родини }\end{array}$ & 8 & 7 & 7 & 6 \\
\hline 082 & 6 & $\begin{array}{l}\text { етичність у } \\
\text { взаєминах } 3 \\
\text { колегами }\end{array}$ & 5 & 5 & 4 & 4 \\
\hline & & Всього & 110 & 100,0 & 110 & 100,0 \\
\hline
\end{tabular}




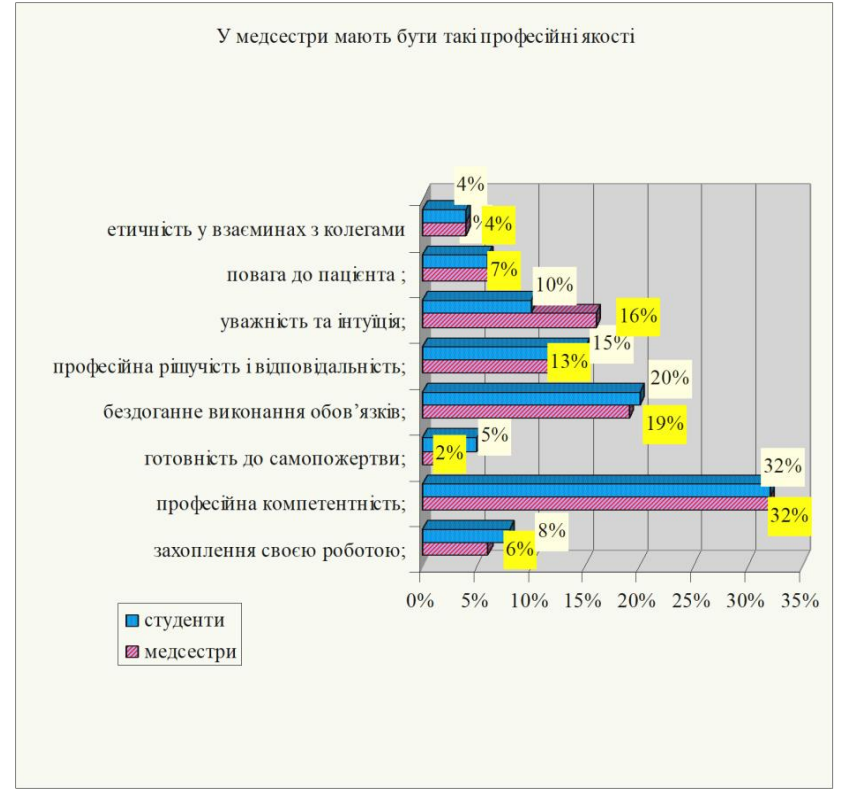

\section{Рис. 16. Структура відповідей респондентів на питання № 15}

Звичайно, така компетентність вміщує цілий комплекс необхідних якостей, в Кодексі медичної сестри зазначено, що вона у своїй діяльності не повинна виходити за межі власної компетентності. $19 \%$ і 20\% респондентів відповідно окремо виділили варіант «бездоганне виконання своїх обов'язків», тоді як 16\% і 10\% обрали варіант «уважність та інтуїцію». При цьому, 7\% працюючих медсестер та 6\% студентів все ж таки акцентували увагу на повазі до пацієнта та його родини. Варіант відповіді «професійна рішучість і відповідальність» обрали 13\% і 15\% респондентів відповідно, ще по $4 \%$ - обрали «етичність у взаєминах з колегами».

За вище наведеними результатами, можна зробити висновок, що медсестри 3 досвідом роботи підходять до вибору варіантів відповідей особистісних та професійних якостей більше 3 практичної точки зору, а студенти - теоретичної.

Щодо конкретного запитання - ціннісно-етичної основи професійної діяльності медичної сестри, відповіді респондентів розподілилися таким чином: 35\% працюючих медсестер і 37\% медсестерстудентів вважають, що нею є моральні (етичні) орієнтири, а 65\% і 
47\% відповідно у вибірках - гуманність і милосердя. Цілком логічно, що більшість респондентів зорієнтувалася на таких варіантах, бо медична етика вивчає і моральні засади у діяльності медичних працівників, і високогуманне ставлення до людини як необхідної умови успішного лікування хворого. Медсестра має також проявляти милість серця, м'якість, співчуття, ніжність, любов до людей, особливо хворих. Серед медсестер-студентів 17\% все ж вказали на релігійні переконання, з якими пов'язують майбутні лінії поведінки медсестри. По-перше, медична сестра немає права порушувати давню етичну заповідь медицини «Не нашкодь!», по-друге, повинна враховувати у своїй роботі те, що пацієнти різного культурного рівня та релігійних переконань можуть по-різному реагувати на медицину й охорону здоров'я.

Таблиця 17

Питання № 16. Етичної основою професійної діяльності медичної сестри є: (Духовні цінності)

\begin{tabular}{|c|c|c|c|c|c|c|}
\hline \multirow[b]{2}{*}{ № } & \multirow[b]{2}{*}{ 紊 } & \multirow[b]{2}{*}{ Варіант відповіді } & \multicolumn{4}{|c|}{\begin{tabular}{|l|l|} 
Відповіді медсестер Відповіді студентів \\
\end{tabular}} \\
\hline & & & $\begin{array}{c}\text { Абс. } \\
\text { кількість }\end{array}$ & Частка,\% & $\begin{array}{c}\text { Абс. } \\
\text { кількість }\end{array}$ & Частка,\% \\
\hline 083 & 2 & моральні оріє & 39 & 35 & 41 & 37 \\
\hline 084 & 1 & $\begin{array}{l}\text { гуманність і } \\
\text { милосердя }\end{array}$ & 71 & 65 & 52 & 47 \\
\hline 085 & 4 & юридичні норл & - & 0 & 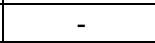 & 0 \\
\hline 086 & 3 & $\begin{array}{l}\text { релігійні } \\
\text { переконання }\end{array}$ & - & 0 & 17 & 16 \\
\hline & & Всього & 110 & 100,0 & 110 & 100,0 \\
\hline
\end{tabular}

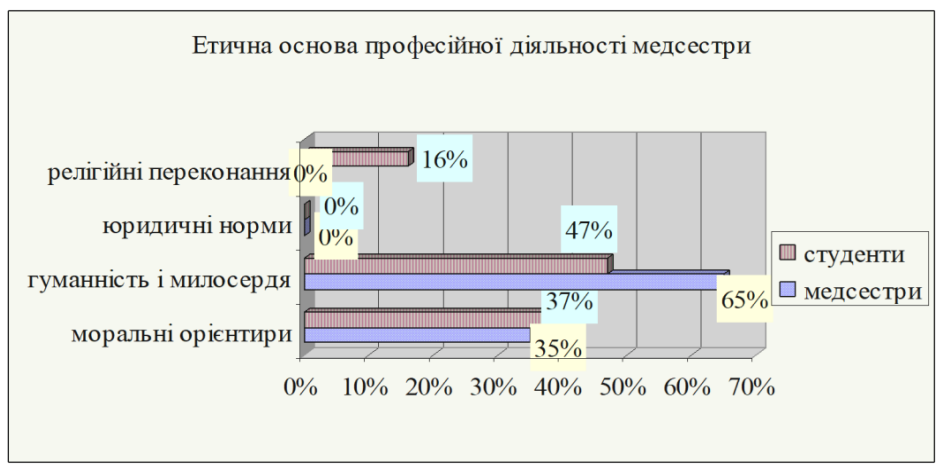

Рис. 17. Структура відповідей респондентів на питання № 16 
Одна з найважчих проблем, перед якою виявляється людина - це вибір професії, адже від цього вибору залежить їі майбутнє. В першу чергу - це відповідальність перед батьками, перед суспільством, а найголовніше перед собою! Ми поцікавилися, що ж вплинуло на вибір професії респондентів?

Таблиця 18

Питання № 17. Що вплинуло на вибір Вашої професії?

(Соціальні ідеали)

\begin{tabular}{|c|c|c|c|c|c|c|}
\hline \multirow[b]{2}{*}{ № } & \multirow[b]{2}{*}{ ڤ } & \multirow[b]{2}{*}{ Варіант відповіді } & \multicolumn{2}{|c|}{ Відповіді медсестер } & \multicolumn{2}{|c|}{ Відповіді студентів } \\
\hline & & & $\begin{array}{c}\text { Абс. } \\
\text { кількість }\end{array}$ & Частка,\% & $\begin{array}{c}\text { Абс. } \\
\text { кількість }\end{array}$ & Частка,\% \\
\hline 087 & 2 & $\begin{array}{l}\text { традиція в родині, } \\
\text { порада батьків }\end{array}$ & 51 & 46 & 37 & 34 \\
\hline 088 & 6 & $\begin{array}{l}\text { престижність в } \\
\text { суспільстві }\end{array}$ & 6 & 5 & 17 & 15 \\
\hline 089 & 4 & порада друзів & 4 & 4 & 1 & 1 \\
\hline 090 & 1 & власний вибір & 47 & 42 & 48 & 44 \\
\hline 091 & 3 & випадок & 2 & 2 & 7 & 6 \\
\hline 092 & 5 & ваш варіант & - & 0 & - & 0 \\
\hline & & Всього & 110 & 100,0 & 110 & 100,0 \\
\hline
\end{tabular}

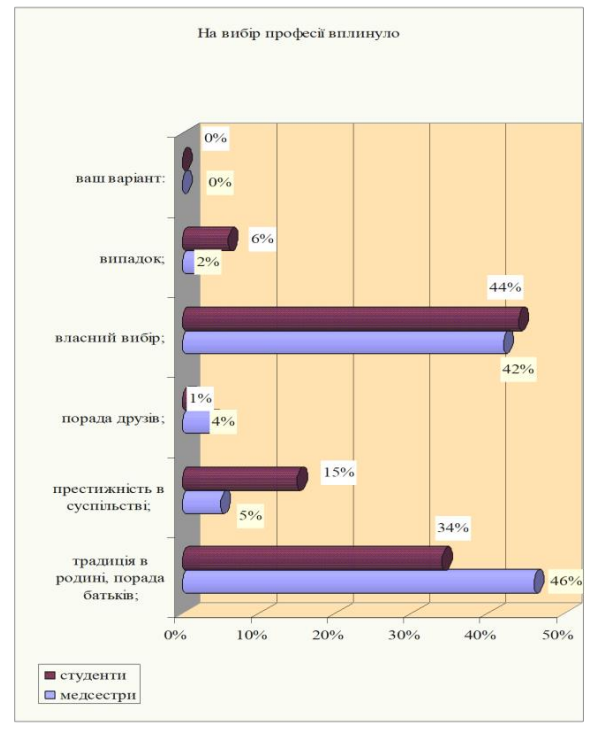

Рис. 18. Структура відповідей респондентів на питання № 17 
Було з'ясовано, що час як категорія і зміни, які відбуваються у суспільстві відіграють свою роль у процесі вибору професії. Так, медсестри, які обрали свій професійний шлях багато років тому у переважній більшості прислухалися до поради батьків та традицій в родині (46\%), тоді як більшість сучасних студентів-медсестер демократичного суспільства здійснили вибір професії за власним бажанням (44\%). При цьому, не нехтували порадами батьків $34 \%$ опитаних студентів, а 42\% працюючих медсестер зробили таки власний вибір професії. На престижність професії в суспільстві вказали $15 \%$ студентів та практично в троє менше працюючих медсестер (5\%). Обрати професію за порадою друзів змогли 4\% працюючих медсестер та $1 \%$ студентів, а випадок - $2 \%$ респондентів серед працюючих медсестер та 6\% серед студентів.

Результати визначення думки респондентів з приводу того, яке місце займає професійна мова в роботі медичної сестри дозволяють з'ясувати, вагомість ще одного елементу аксіологічної системи. Так у медичних сестер професійній мові відводиться важливе місце, про свідчать 60\% таких варіантів відповідей.

Таблиця 19

\section{Питання № 18. Місце професійної мови в роботі медсестри} (Профбесійна мова)

\begin{tabular}{|c|c|c|c|c|c|c|}
\hline \multirow[b]{2}{*}{ № } & \multirow[b]{2}{*}{$\stackrel{1}{\pi}$} & \multirow{2}{*}{$\begin{array}{c}\text { Варіант } \\
\text { відповіді }\end{array}$} & \multicolumn{2}{|c|}{ Відповіді медсестер } & \multicolumn{2}{|c|}{ Відповіді студентів } \\
\hline & & & $\begin{array}{c}\text { Абс. } \\
\text { кількість }\end{array}$ & Частка,\% & $\begin{array}{c}\text { Абс. } \\
\text { кількість }\end{array}$ & Частка,\% \\
\hline 093 & 1 & важлива & 66 & 60 & 49 & 45 \\
\hline 094 & 3 & неважлива & 8 & 7 & 28 & 25 \\
\hline 095 & 2 & $\begin{array}{c}\text { власний } \\
\text { варіант }\end{array}$ & 36 & 33 & 33 & 30 \\
\hline \multicolumn{3}{|c|}{ Всього } & 110 & 100,0 & 110 & 100,0 \\
\hline
\end{tabular}

При цьому, 7\% працюючих медсестер вважають, що мова не відіграє значущої ролі при виконанні професійних обов'язків, а власні варіанти відповідей запропонували 33\% опитаних. Всі вони відображають серйозне і надважливе ставлення до професійної мови, оскільки, оволодіння основними способами розв'язання професійних завдань неможливе без оволодіння мовою професійного спілкування. Щодо студентів, важливе місце мові відвели $45 \%$ опитаних, неважливе $-25 \%$ і приблизно такі ж варіанти власних відповідей, як у медсестер запропонували $30 \%$ опитаних. 


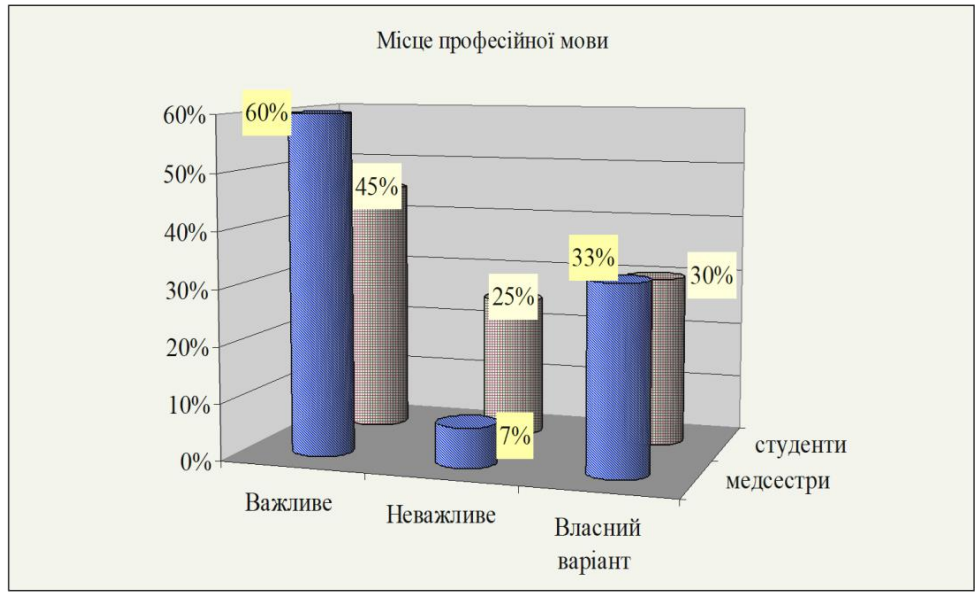

Рис. 19. Структура відповідей респондентів на питання № 18

На питання «чи розвивають в процесі роботи (або навчання) у Вас цінність любові до життя та вміння боротися за життя пацієнта?» відповіді розподілилися так: абсолютна більшість (по 94\% в кожній вибірці) опитаних дали ствердну відповідь. Лише по 6\% респондентів в обох вибірках вагалися відповісти. Адже, медична сестра усвідомлює свою відповідальність за безцінне - життя хворого, яке втратити легко, а повернути неможливо.

Таблиця 20

Питання № 19. Чи розвивають в процесі роботи (або навчання) у Вас цінність любові до життя та вміння боротися за життя пацієнта (Цінність любові до життя)

\begin{tabular}{|c|c|c|c|c|c|c|}
\hline \multirow[b]{2}{*}{ № } & \multirow[b]{2}{*}{ 20 } & \multirow[b]{2}{*}{$\begin{array}{c}\text { Варіант } \\
\text { відповіді }\end{array}$} & \multicolumn{2}{|c|}{ Відповіді медсестер } & \multicolumn{2}{|c|}{ Відповіді студентів } \\
\hline & & & $\begin{array}{c}\text { Абс. } \\
\text { кількість }\end{array}$ & Частка,\% & $\begin{array}{c}\text { Абс. } \\
\text { кількість }\end{array}$ & Частка,\% \\
\hline 095 & 1 & так & 103 & 94 & 103 & 94 \\
\hline 096 & 3 & $\mathrm{Hi}$ & 0 & 0 & - & 0 \\
\hline 097 & 2 & $\begin{array}{l}\text { вагаються } \\
\text { відповісти } \\
\end{array}$ & 7 & 6 & 7 & 6 \\
\hline \multicolumn{3}{|c|}{ Всього } & 110 & 100,0 & 110 & 100,0 \\
\hline
\end{tabular}




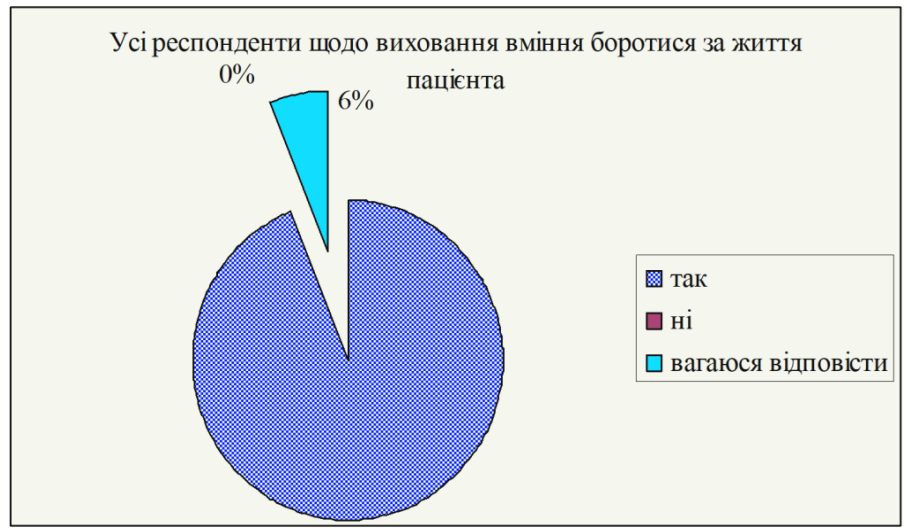

Рис. 20. Структура відповідей респондентів на питання № 19

На завершення опитування, було представлено питання: на що ж впливає професійна культура, система цінностей медичної сестри? На думку більшості опитаних працюючих медсестер (57\%) та майбутніх медсестер (55\%), вона впливає на розвиток особистості, а на думку інших працюючих медсестер (43\%) та студентів (45\%), вона впливає все таки на кар'єрний ріст. В обох вибірках варіант відповіді «на зарплату» не вибрав жоден респондент.

Таблиця 21

Питання № 20. Професійна культура медичної сестри впливає на (Переконання)

\begin{tabular}{|c|c|c|c|c|c|c|}
\hline \multirow[b]{2}{*}{ № } & \multirow[b]{2}{*}{$\stackrel{5}{a}$} & \multirow[b]{2}{*}{ Варіант відповіді } & \multicolumn{2}{|c|}{ Відповіді медсестер } & \multicolumn{2}{|c|}{ Відповіді студентів } \\
\hline & & & $\begin{array}{c}\text { Абс. } \\
\text { кількість }\end{array}$ & Частка,\% & $\begin{array}{c}\text { Абс. } \\
\text { кількість }\end{array}$ & Частка,\% \\
\hline 094 & 2 & кар'єрний зріст & 47 & 43 & 50 & 45 \\
\hline 095 & 3 & розмір зарплати & - & 0 & - & 0 \\
\hline 096 & 1 & \begin{tabular}{|l|} 
розвиток \\
особистості
\end{tabular} & 63 & 57 & 60 & 55 \\
\hline & & Всього & 110 & 100,0 & 110 & 100,0 \\
\hline
\end{tabular}

У підсумку, обидві групи респондентів не помилилися. Професійна культура медичної сестри 3 відповідною системою цінностей $\epsilon$ однією з необхідних умов високої ефективності праці в суспільстві. В першу чергу, вона впливає на розвиток особистості, а вже ця особистість буде спроможна здійснити власний кар'єрний ріст. 


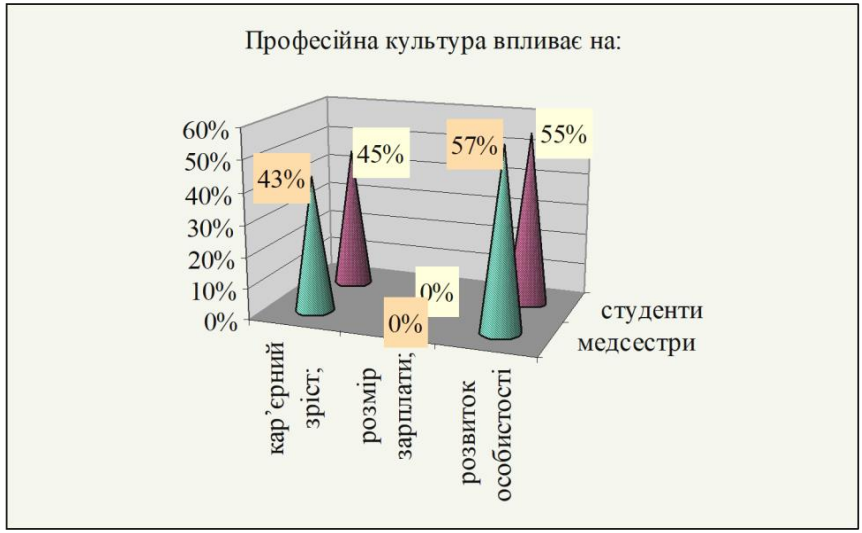

Рис. 21. Структура відповідей респондентів на питання № 20

Символ - інтенція зв'язку цінностей теперішнього до майбутнього. Адже, символ - це те, що у своїй почуттєвій якості вказує на щось інше чи заміщає щось інше, під яким може розумітися конкретне явище чи предмет. Ми запитали у респондентів: «який символ має медсестринство?» На дане запитання працюючі медсестри у 40\% відповідей вказали на «червоний хрест», майже стільки ж вказали на цей символ студенти. Більшість студентів (55\%) обрали символ «жінка з ліхтариком», тоді як це зробили $30 \%$ працюючих медсестер. Символ «змія 3 чашею» обрали $30 \%$ медсестер та 8\% студентів.

Таблиця 22

Питання № 21. Який символ має медсестринство у медичній сфері? (Символи)

\begin{tabular}{|c|c|c|c|c|c|c|}
\hline \multirow{2}{*}{ № } & \multirow{2}{*}{ 音 } & \multirow{2}{*}{ Варіант відповіді } & \multicolumn{2}{|c|}{$\begin{array}{l}\text { Відповіді } \\
\text { медсестер }\end{array}$} & \multicolumn{2}{|c|}{$\begin{array}{l}\text { Відповіді } \\
\text { студентів }\end{array}$} \\
\hline & & & $\begin{array}{c}\text { Абс. } \\
\text { кількість }\end{array}$ & Частка,\% & $\begin{array}{c}\text { Абс. } \\
\text { кількість }\end{array}$ & Частка,\% \\
\hline 097 & 2 & червоний хрест & 44 & 40 & 41 & 37 \\
\hline 098 & 3 & змія з чашею & 33 & 30 & 9 & 8 \\
\hline 099 & 1 & жінка з ліхтариком & 33 & 30 & 60 & 55 \\
\hline 100 & 4 & ваш варіант & - & - & - & - \\
\hline & & Всього & 110 & 100,0 & 110 & 100,0 \\
\hline
\end{tabular}




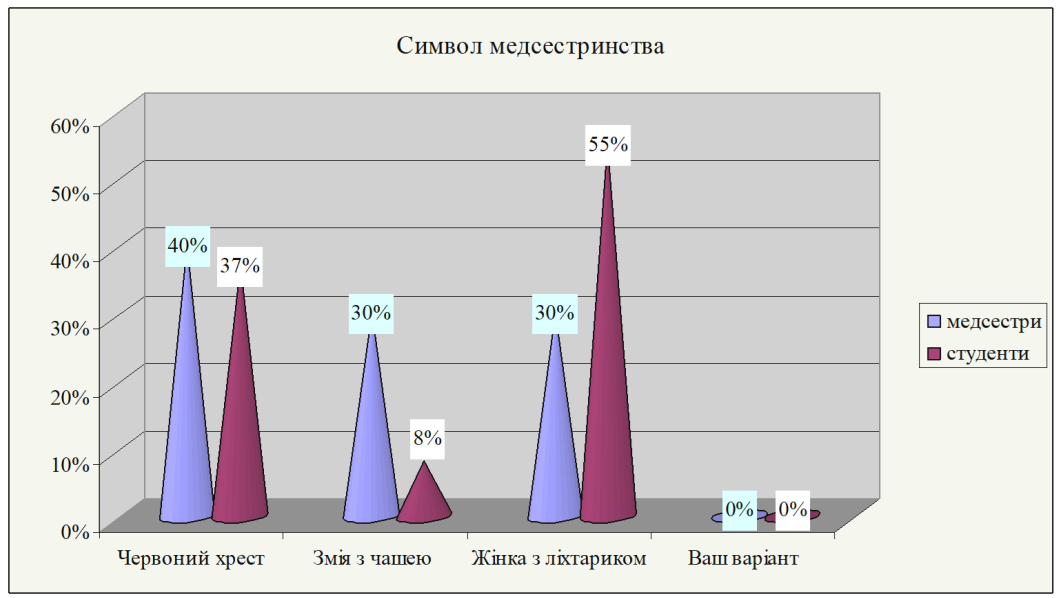

Рис. 22. Структура відповідей респондентів на питання № 21

\section{Висновки}

Статистична обробка отриманих даних опитувальника дозволило виявити статистично значимі відмінності між вибірками студентів та медсестер по окремих питаннях анкети. Для аналізу використовувалися коефіцієнт кореляції (критерій Спірмена), та порівняння незалежних груп (критерій U Манна-Уїтні). Ми свідомо обрали непараметричні, рангові критерії, оскільки їх можливо застосовувати для обчислень даних як 3 нормальним та з не нормальним розподілом.

Критерій U Манна-Уїтні показав такі статистично значимі відмінності у відповідях на запитання: 1) Що для вас означає любити життя? (цінувати кожну хвилину свого життя - $\mathrm{U}=1134, \mathrm{r}_{\mathrm{s}}=0,152$, $\mathrm{p} \leq 0,05$; боротися за безсмертя - $\mathrm{U}=144, \mathrm{r}_{\mathrm{s}}=-0,268, \mathrm{p} \leq 0,05$; кохати та посміхатися - $\mathrm{U}=646, \mathrm{r}_{\mathrm{s}}=0,367, \mathrm{p} \leq 0,001$; відчувати себе щасливим $\mathrm{U}=692, \mathrm{r}_{\mathrm{s}}=0,301, \mathrm{p} \leq 0,01$; цінувати життя та здоров'я - $\mathrm{U}=1442$, $\left.\mathrm{r}_{\mathrm{s}}=0,152, \mathrm{p} \leq 0,001\right) ; 2$ ) Що Ви розумієте під поняттям гуманна людина? (людина, яка контролює свої емоції - $\mathrm{U}=1872, \mathrm{r}_{\mathrm{s}}=0,245$, $\mathrm{p} \leq 0,01)$; 3) Які цінності для Вас займають перше місце? (здоров'я $\left.\mathrm{U}=2074, \mathrm{r}_{\mathrm{s}}=0,209, \mathrm{p} \leq 0,01\right)$; 4) Які особисті якості мають бути у медичної сестри? (старанність - $\mathrm{U}=1342, \mathrm{r}_{\mathrm{s}}=-0,218, \mathrm{p} \leq 0,01$; наполегливість - $\mathrm{U}=1134, \mathrm{r}_{\mathrm{s}}=-0,238, \mathrm{p} \leq 0,05$; щедрість - $\mathrm{U}=1442$, $\left.\mathrm{r}_{\mathrm{s}}=-0,216, \mathrm{p} \leq 0,05\right)$; 5) Які професійні якості мають бути у медичної сестри? (професійна рішучість та відповідальність - U=1298, 
$\left.\left.r_{s}=-0,246, p \leq 0,01\right) ; 6\right)$ Чи розвиваються в процесі навчання у Вас цінність любові дожиття та вміння боротися за життя пацієнта? - $\mathrm{U}=1848, \mathrm{r}_{\mathrm{s}}=0,152, \mathrm{p} \leq 0,05$.

Ми можемо припустити, що зниження значимості таких особистих та професійних якостей у медсестер, порівняно зі студентами, як старанність, наполегливість, щедрість,професійна рішучість та відповідальність пов'язане з професійним вигоранням, погіршенням стану здоров'я та низьким соціальним статусом професії. В процесі здійснення професійної діяльності медсестри втрачають студентські ідеалістичні уявлення про роботу медичної сестри і стають більш приземленими, прагматичними, пасивними, відбувається адаптація особистісних цінностей до цінностей, що культивуються в суспільстві, які часто поглиблюють протиріччя між спільнотою та їі представниками, між цінностями персоналі стичними та соціальними.

Таким чином, отримані в результаті опитування дані, дозволили виділити показники компонентів професійної медичної системи цінностей, які визначають особливості сучасної медичної культури та складають її ядро та периферію окремо в обох вибірках. Для цього додатково було виділено ряд питань з анкети та проранжовано варіанти відповідей (від 1 до 6 в порядку зменшення вагомості впливу на остаточний результат). Далі виконано математичні розрахунки основних коефіцієнтів по вибірці медсестри (К медсестри) та по вибірці студенти (К студенти) за рангом 1 окремих варіантів відповідей (див. додаток Б).

Застосовано формулу знаходження середньої величини:

$$
\text { Коефіцієнт [елемент }
$$

де $\Sigma$ - знак суми хі - варіант відповіді за значущим рангом 1; $\mathrm{n}$ - кількість оброблених питань по виділеному елементу.

I. Цінність любові людини до життя (опрацьовано 6 питань (№ $1,2,3,6,9,19$ ):

$$
\begin{gathered}
\text { Кмедсестри }[\text { Філом. цінність }]=\frac{\sum x i}{n}=; \\
=\frac{80 \%+68 \%+62 \%+63 \%+78 \%+94 \%}{6} \%=74 \%
\end{gathered}
$$




$$
\begin{gathered}
\text { Кстуденти }[\text { Філом. цінність }]=\frac{\sum x i}{n}=. \\
=\frac{26 \%+26 \%+45 \%+18 \%+59 \%+94}{6} \%=47 \%
\end{gathered} .
$$

II. Норми взаємодії з керівництвом (опрацьовано 1 питання №12):

Кмедсестри $[$ Норми·взаємодіi $]=\frac{\sum x i}{n}=\frac{65 \%}{1} \%=65 \%$;

Кстуденти $[$ Норми·взаємодіi $]=\frac{\sum x i}{n}=\frac{90 \%}{1} \%=90 \%$.

III. Професійна мова (опрацьовано 1 питання №18):

$$
\begin{gathered}
\text { Кмедсестри }[\text { Проф. } \cdot \text { мова }]=\frac{\sum x i}{n}=\frac{60 \%}{1} \%=60 \% \\
\text { Кстуденти }\left[\text { Проф. } \cdot \text { мова] }=\frac{\sum x i}{n}=\frac{45 \%}{1} \%=45 \% .\right.
\end{gathered}
$$

IV. Переконання (опрацьовано 1 питання №20):

$$
\begin{gathered}
\text { Кмедсестри[Переконання }]=\frac{\sum x i}{n}=\frac{57 \%}{1} \%=57 \% ; \\
\text { Кстуденти [Переконання] }=\frac{\sum x i}{n}=\frac{55 \%}{1} \%=55 \% .
\end{gathered}
$$

V. Професійні навички і вміння (опрацьовано 1 питання № 11): Кмедсестри $[$ Проф. вміння, $\cdot$ навички $]=\frac{\sum x i}{n}=\frac{56 \%}{1} \%=56 \%$; Кстуденти $[$ Проф. •вміння, $\cdot$ навички $]=\frac{\sum x i}{n}=\frac{40 \%}{1} \%=40 \%$. 
VI. Духовні цінності (опрацьовано 2 питання №13, 16):

Кмедсестри [Духовна. цінність $]=\frac{\sum x i}{n}=\frac{45 \%+65 \%}{2} \%=55 \%$; Кстуденти[ Духовна. ицінність $]=\frac{\sum x i}{n}=\frac{20 \%+47 \%}{2} \%=33 \%$.

VII. Особисті якості (опрацьовано 1 питання №14):

Кмедсестри $[$ Особисті ·цінності $]=\frac{\sum x i}{n}=\frac{36 \%}{1} \%=36 \%$;

Кстуденти [Особисті. иінності $]=\frac{\sum x i}{n}=\frac{28 \%}{1} \%=28 \%$.

VIII. Стандарти поведінки (опрацьовано 1 питання №15):

Кмедсестри $[$ Проф. якості $]=\frac{\sum x i}{n}=\frac{32 \%}{1} \%=32 \%$;

Кстуденти $[$ Проф. $\cdot$ якості $]=\frac{\sum x i}{n}=\frac{32 \%}{1} \%=32 \%$.

IX. Соціальні ідеали (опрацьовано 2 питання № 10, 17):

Кмедсестри $[$ Соціальні $\cdot$ ідеали $]=\frac{\sum x i}{n}=\frac{19 \%+42 \%}{2} \%=30 \%$;

Кстуденти $[$ Соціальні ·деели $]=\frac{\sum x i}{n}=\frac{18 \%+44 \%}{2} \%=31 \%$.

Х. Символи (опрацьовано 1 питання № 21):

Кмедсестри $[$ Символи $]=\frac{\sum x i}{n}=\frac{30 \%}{1} \%=30 \%$; 


$$
\text { Кстуденти }[\text { Символи }]=\frac{\sum x i}{n}=\frac{55 \%}{1} \%=55 \%
$$

Завершальним етапом $є$ укладання отриманих часток в елементи «ядро» та «периферія». Використання такого способу обробки даних обгрунтовано тим, що це $є$ пара взаємопов'язаних понять, яка використовується для розуміння суті класифікації отриманих елементів професійної медичної системи цінностей, культури в цілому. «Ядро» - основна маса елементів, а «периферія»- сукупність інших розрізнених елементів.

Таблиця 23

\section{Елементи професійної культури та відповідної системи} цінностей за класифікацією системи «ядро - периферія»

\begin{tabular}{|l|c|c|}
\hline \multicolumn{1}{|c|}{ Системоутворюючі елементи } & $\begin{array}{c}\text { Вибірка I. } \\
\text { Працюючі } \\
\text { медсестри,\% }\end{array}$ & $\begin{array}{c}\text { Вибірка II. } \\
\text { Студенти - } \\
\text { майбутні } \\
\text { медсестри,\% }\end{array}$ \\
\hline I. Філоменологічна цінність & $\mathbf{7 4}$ & 47 \\
\hline $\begin{array}{l}\text { II. Норми взаємодії } \\
\text { керівництвом }\end{array}$ & 65 & $\mathbf{9 0}$ \\
\hline III. Професійна мова & 60 & 45 \\
\hline IV. Переконання & 57 & 55 \\
\hline V. Професійні навички і вміння & 56 & 40 \\
\hline VI. Духовні цінності & 55 & 33 \\
\hline VII. Особисті якості & 36 & 28 \\
\hline VIII. Стандарти поведінки & 32 & 32 \\
\hline IX. Соціальні ідеали & 30 & 31 \\
\hline Х. Символи & 30 & 55 \\
\hline
\end{tabular}

Отже, ключовими елементами, які дозволяють виявити місце генеральної цінності («любов людини до життя») як в структурі професійної культури, так і в системі ціннісних орієнтирів особистості, ми вважаємо відповідь «Життя - це божий дар» на перше запитання анкети «Життя - це?..» та ствердну відповідь на запитання «Чи розвиваються в процесі навчання у Вас цінність до життя?». Кореляційний аналіз виявив, що респонденти, які обрали варіант «Життя - це Божий дар» показують стійку позитивну кореляцію $з$ такими якостями, як альтруїзм $\left(\mathrm{r}_{s}=0,363, \mathrm{p} \leq 0,01\right)$, та негативну 3 егоїстичними тенденціями $\left(\mathrm{r}_{\mathrm{s}}=-0,311, \mathrm{p} \leq 0,01\right)$. Вони відзначаються кращим станом здоров'я й показують менший рівень 
кількості хронічних захворювань. Ці респонденти приділяють менше значення руховим вмінням та навичкам $\left(\mathrm{r}_{\mathrm{s}}=-0,275, \mathrm{p} \leq 0,01\right)$ та більше - перцептивним навичкам $\left(\mathrm{r}_{\mathrm{s}}=0,239, \mathrm{p} \leq 0,01\right)$ та емпатії $\left(\mathrm{r}_{\mathrm{s}}=0,347, \mathrm{p} \leq 0,001\right)$ у професійній діяльності медичної сестри. Вони високо оцінюють соціальне значення професій медичної сестри $\left(\mathrm{r}_{\mathrm{s}}=0,275, \mathrm{p} \leq 0,01\right)$, а також значення таких особистих та професійних якостей як милосердя $\left(\mathrm{r}_{\mathrm{s}}=0,284, \mathrm{p} \leq 0,01\right)$, наполегливість $\left(\mathrm{r}_{\mathrm{s}}=0,287\right.$, $\mathrm{p} \leq 0,001)$, доброта $\left(\mathrm{r}_{\mathrm{s}}=0,245, \mathrm{p} \leq 0,01\right)$, охайність $\left(\mathrm{r}_{\mathrm{s}}=0,334, \mathrm{p} \leq 0,001\right)$, захопленість своєю роботою $\left(\mathrm{r}_{\mathrm{s}}=0,275, \mathrm{p} \leq 0,01\right)$, бездоганне виконання професійних обов'язків $\left(\mathrm{r}_{\mathrm{s}}=0,275, \mathrm{p} \leq 0,01\right)$, уважність та інтуїція $\left(\mathrm{r}_{\mathrm{s}}=0,275, \mathrm{p} \leq 0,01\right)$, повага до пацієнта і його родини $\left(\mathrm{r}_{\mathrm{s}}=0,275\right.$, $\mathrm{p} \leq 0,01)$.

В той час, як опитані, які не показали високого рівня цінності любові до життя і дали суто формальну відповідь «Життя - це форма існування» показали протилежні результати. Порівняно нижчий рівень альтруїзму $\left(\mathrm{r}_{\mathrm{s}}=-0,303, \mathrm{p} \leq 0,05\right)$ та емпатії $\left(\mathrm{r}_{\mathrm{s}}=-0,180, \mathrm{p} \leq 0,05\right)$, вищий рівень хронічних захворювань $\left(\mathrm{r}_{\mathrm{s}}=0,253, \mathrm{p} \leq 0,01\right)$, низьку оцінку такої професійної якості, як поваго до пацієнта та його родини $\left(\mathrm{r}_{\mathrm{s}}=-0,285, \mathrm{p} \leq 0,01\right)$. Вони схильні негативно відповідати на запитання «Чи розвивається у Вас в процесі навчання цінність любові до життя та вміння боротися за життя пацієнта?» $\left(\mathrm{r}_{\mathrm{s}}=-0,261, \mathrm{p} \leq 0,01\right)$.

Респонденти, які ствердно відповіли на запитання «Чи розвиваються в процесі навчання у Вас цінність до життя?», більш гостро відчувають цінність кожної миті життя $\left(\mathrm{r}_{\mathrm{s}}=0,353, \mathrm{p} \leq 0,001\right)$, менше схильні до егоїзму $\left(\mathrm{r}_{\mathrm{s}}=-0,253, \mathrm{p} \leq 0,05\right)$, їх менше хвилює швидка втомлюваність $\left(\mathrm{r}_{\mathrm{s}}=-0,212, \mathrm{p} \leq 0,05\right)$, вони більш стресостійкі $\left(\mathrm{r}_{\mathrm{s}}=0,246\right.$, $\mathrm{p} \leq 0,01)$ та менш дратівливі $\left(\mathrm{r}_{\mathrm{s}}=-0,645, \mathrm{p} \leq 0,001\right)$, більш стійко переносять життєві негаразди. Для цих опитаних більш важливі духовні цінності $\left(\mathrm{r}_{\mathrm{s}}=0,256, \mathrm{p} \leq 0,01\right)$. Вони показують вищу оцінку таких якостей, як впевненість в собі $\left(\mathrm{r}_{\mathrm{s}}=0,181, \mathrm{p} \leq 0,05\right)$, уважність та інтуїція $\left(\mathrm{r}_{\mathrm{s}}=0,190, \mathrm{p} \leq 0,05\right)$, повага до пацієнта та його родини $\left(\mathrm{r}_{\mathrm{s}}=0,282, \mathrm{p} \leq 0,01\right)$. А також обробка результатів анкетування свідчить, що вони не випадково, свідомо обрали професію медичної сестри.

В контексті сказаного слід зазначити, що респонденти, які зазначили, що випадково обрали спеціальність медичної сестри, менш схильні цінувати кожну хвилину життя $\left(-\mathrm{r}_{\mathrm{s}}=0,311, \mathrm{p} \leq 0,01\right)$. Більш схильні до хронічних захворювань $\left(\mathrm{r}_{\mathrm{s}}=0,223, \mathrm{p} \leq 0,05\right)$ та проблем 3 проблем 3 травленням $\left(\mathrm{r}_{\mathrm{s}}=0,185, \mathrm{p} \leq 0,05\right)$. Показують низьку стресостійкість $\left(\mathrm{r}_{\mathrm{s}}=-0,284, \mathrm{p} \leq 0,01\right)$ та високу дратівливість $\left(\mathrm{r}_{\mathrm{s}}=0,329, \mathrm{p} \leq 0,001\right)$. Показують низьку готовність виконувати 
вказівки лікаря $\left(\mathrm{r}_{\mathrm{s}}=-0,297, \mathrm{p} \leq 0,001\right)$ низька оцінка таких якостей як наполегливість $\left(\mathrm{r}_{\mathrm{s}}=-0,201, \mathrm{p} \leq 0,05\right)$, терпеливість $\left(\mathrm{r}_{\mathrm{s}}=-0,304, \mathrm{p} \leq 0,001\right)$, захопленість своєю роботою $\left(\mathrm{r}_{\mathrm{s}}=-0,230, \mathrm{p} \leq 0,05\right)$. У них не розвивається в процесі навчання цінність любові дожиття та вміння боротися життя пацієнта $\left(\mathrm{r}_{\mathrm{s}}=0,-246, \mathrm{p} \leq 0,01\right)$.

Таким чином, ми можемо стверджувати, що виховання як професійної культури загалом, так і генеральної цінності «цінності любові людини до життя», як її фундаменту, зокрема, у підготовці медичних сестер сприятиме їхньому особистісному та професійному зростанню, по-перше. По-друге, викристалізувалася ціннісна основа людей, з якими медична сфера може пов'язувати своє майбутнє та реалізацію освітянського вектора Education 5.0.

\section{Література}

1. Морен Э. Метод. Природа Природы. Москва : ПрогрессТрадиция, 2005. 464 с.

2. Фрейре П. Педагогіка пригноблених / пер. з англ. О. Дем'янчук. Київ: Юніверс, 2003. 168 с.

3. Panetta K. Blockchain, quantum computing, augmented analytics and artificial intelligence will drive disruption and new business models. Gartner Top 10 Strategic Technology Trends for 2019 : веб-сайт. URL: https://www.gartner.com/smarterwithgartner/gartner-top-10-strategictechnology-trends-for-2019

4. Хейлал У. Е. Десять ведущих технологий будущего. Halal W. E. The top 10 emerging technologies. Futurist. 2000. Vol. 34, № 4. P. 1-10.

5. The future jobs. Study international: веб-сайт. URL: https:// www.weforum.org/reports/the-future-of-jobs

6. Гэйбл Э. Цифровая трансформация школьного образования. Международный опыт, тренды, глобальные рекомендации / пер. с англ. П.А. Сергоманова. Москва, 2019. 108 с.

7. Keser H., Semerci A. Technology trends, Education 4.0 and beyond. Contemporary Educational Researches Journal. 2019. № 9(3) Pp. 39-49. DOI: https://doi.org/10.18844/cerj.v9i3.4269

8. Д'яченко I.M. Антропологічний поворот у педагогіці: теоретико-методологічний пошук фундаментальної цінності діяльності людини. Journal «ScienceRise:Pedogogical Education». 2019. № 1(28). C. 29-37. DOI: https://doi.org/10.15587/2519-4984.2019.155266

9. Hong H. Y., Chiu C. H. Understanding how students perceive the role of ideas for their knowledge work in a knowledge-building environment. Australasian Journal of Educational Technology. 2016. № 32(1). P. 32-46. 